\title{
TANNER
}

Bacteria in Deep Wells and

\author{
Surface Waters
}

Chemistry

M. S.

Ig14 
Q. $(i 2 \pi),(\because 20)$

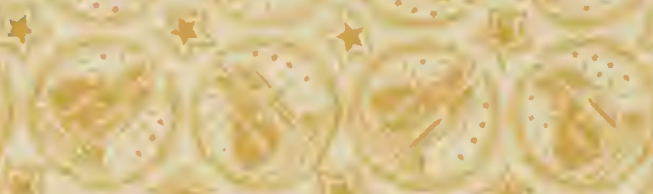

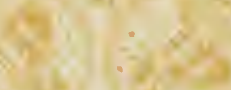

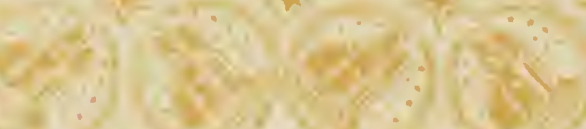

․․

2,8

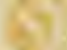

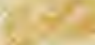

4.

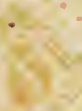

a

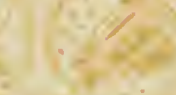

$3 \because$
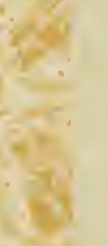

THE UNIVERSITY

\section{OF ILLINOIS}

\section{LIBRARY}

1914

T 16

(2)

$x$

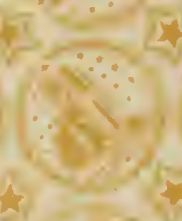

$\therefore y^{2}$
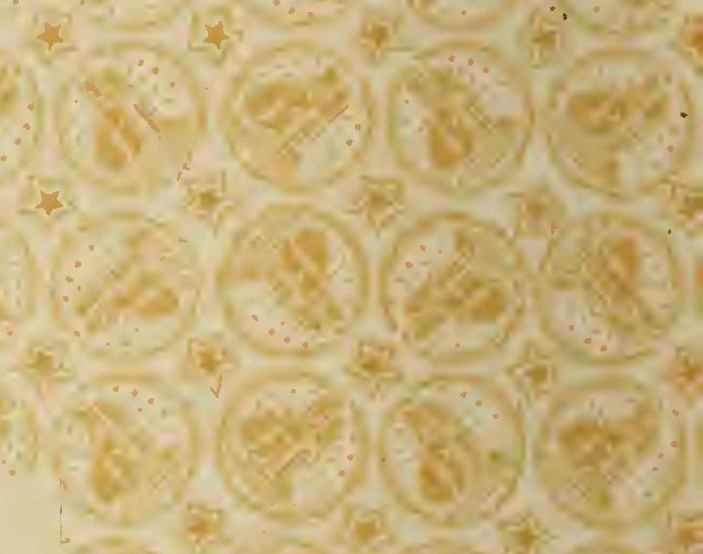

\section{$i_{i 2}, 2=$}
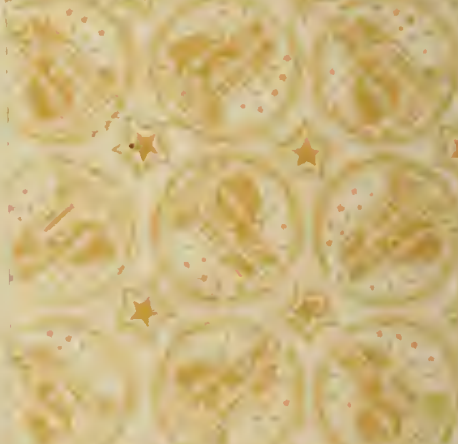

A)

(5)

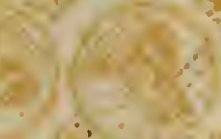

$$
\text { , }
$$


Digitized by the Internet Archive in 2013 
BACTERIA IN DEEP WELLS AND SURFACE WATERS

BY

FRED WILBUR TANNER

B. S. Wesleyan University, 1912

\author{
THESIS \\ Submitted in Partial Fulfillment \\ of the Requirements for the \\ Degree of \\ MASTER OF SCIENCE \\ IN CHEMISTRY \\ IN \\ THE GRADUATE SCHOOL \\ OF THE \\ UNIVERSITY OF ILLINOIS \\ 1914
}





\section{4 \\ $+16$}

UNIVERSITY OF ILLINOIS

THE GRADUATE SCHOOL

June 1, 1914

I HEREBY RECOMMEND THAT THE THESIS PREPARED UNDER MY SUPERVISION BY

\section{FRED VIIBUR TAIIIER}

ENTITLED BACIERIA IN DHEP WEILLS AND SURHACE WATER.

BE ACCEPTED AS FULFILLING THIS PART OF THE REQUIREMENTS FOR THE

DEGREE OF

MASTIR OF SCIEUTCE

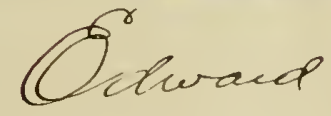

Oalow.

In Charge of Major Work

W. A. $\sqrt{6}$

Head of Department

Recommendation concurred in:

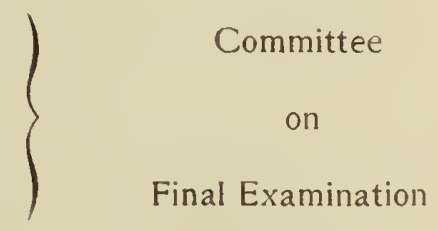





\section{I D E X}

Part I (A)

Bacteria in Deep Wells.................... Page

Part I (B)

Bacillus colon in Grouna Waters............. 9

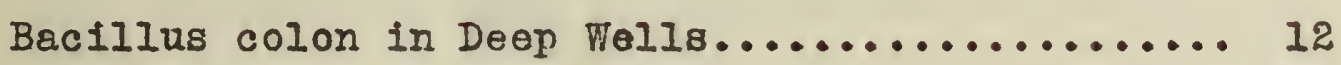

Isolation of Bacteria................... I8

Part II

Surface Waters........................ 25 Bibliography $\ldots \ldots \ldots \ldots \ldots \ldots \ldots \ldots \ldots \ldots \ldots \ldots \ldots \ldots \ldots$ 



\section{BACTERIA IN DEIPP WELTS AID SUREACE WATERS}

Of all living things, bacteria are most widely distributed over the surface of the earth. As is the case with higher animals, we find a definite habitat for a particular species of bacteria. There are certain places where some can exist in greater numbers than can others. We sometimes find species in an environment quite different from the normal.

\section{PART I (A)}

\section{Bacteria in Deep Nells.}

Water coming from underground sources was, until recently, considered sterile. Many older text books claimed that there were no bacteria in water from underground sources. More recently, however, investigators have reported bacteria in deep well waters, until at the present time, most text books grant that a ground water may contain bacteria. Frankland reports from 6 to 26 cells per co. in a Kent well sunk in chalk. He gives no information with regard to the methods used in securing the results. Breunig ${ }^{22}$ found from 6 to 30 bacteria per cc. in some artesian wells at Kiel. The medium used is not given. Huoppe is reported to have found only four in a deep well at Wiesbaden where a special investigation was 

carried on. In the Hainz weIls Egerer found four colonies. Savage ${ }^{2}$ claims that deep well water having been filtered through layers of earth should contain few bacteria and should be subject to very little variation. On gelatin the number of bacteria is usually less than 50 per cc. and on agar less than 1 per co.

Prescott and $M 1 n s l o w^{3}$ quote analyses of deep wells and springs in the neighborhood of Boston in which the number of bacteria varied from 0 to 12. They reach the conclusion that water absolutely free from bacteria is not ordinarily secured from any source.

Thresh ${ }^{4}$ gives many instances of bacteria in ground waters and especially of the intestinal flore coming under his own observation. Some of these will be mentioned later. 
-

$\cdot \operatorname{low}, *+\cdot 1,+r$ 
The results in the following table indicate the number of bacteria found in some IIIInois deep wells:

$\begin{array}{cccc}\text { Sample No. } & \begin{array}{c}\text { Depth } \\ \text { (ft.) }\end{array} & \text { Afar } & \text { Gelatin } \\ 27452 & 282 & 9 & 55 \\ 27474 & 400 & 0 & 0 \\ 27475 & 160 & 1 & 1 \\ 27476 & 160 & 28 & 30 \\ 27477 & 120 & -\infty & 6 \\ 27545 & 211 & 4 & 10 \\ 27557 & 895 & 0 & 20 \\ 27568 & 113 & 4 & 3 \\ 27582 & 2000 & 1 & 9 \\ 27611 & 126 & 0 & 2 \\ 27612 & 126 & 0 & 6 \\ 27672 & 270 & 4 & 10\end{array}$

\section{EXP IRIMANTAS}

It was thot advisable to investigate the character of the colonies found on some of the plates of water from underground sources. These wells are located at different points in the state of IIlinois and all are strictly speaking deep wells. Only those samples were considered which were known to be from wells which had been pumped for some time. Very often it was found that a badly contaminated deep well water came fror a now woll which had been thoroly flushed out. The work here presented was done on the samples as they came to the State Fater survey for the routine analysis. 

Method of Procedure. The water was plated on agar and incubated at $37^{\circ} \mathrm{C}$ and on gelatin at $20^{\circ} \mathrm{C}$. After these plates had been counted, colonies were picked off by means of a sterile platinum wire and transferred to agar slants. These cultures were later plated, in dilution, on gelatin in order to secure a pure culture. The cultural characteristics were then determined by means of the different standard media and the results recorded on the charts of the Soclety of American Bacteriologists.

Sample A.

A well 1382' deep located at odell, Illinois, furnished this water. It was comparatively now, but had been purped for some time before the sample was sent in. The well is cased with iron pipe and the cover is water tight. The water is securec from the St. Peter sandatone.

The number of bacteria on agar vas 26 and on gelatin, 1000. The high number of bacteria on gelatin may have been due to the fact that the casing had not been thoroly flushed out when the sample was taken. The two following bacteria were taken from the gelatin plates and subjected to the different kinds of media mentioned below. The colonies were of the sane general shape varying only in size. All grew on the surface and were colored slightly brown.at their centers. The gelatin plates began to liquefy in less than forty-eight hours. 



\section{Bacillus subtilus.}

Diameter: Iess than 1 micron.

Spores: Formed toward midale of the rod.

Motility: Motile when taken from fresh broth medium.

Gram: Positive.

Broth: Turbid with pellicle.

Gelatin plate: Gelatin is liquefied in about 40 hours.

Thru the liquid granules occur.

Potato: Rioh wrinkled growth.

Milk: Coagulated.

Indol: Negative.

Nitrates: Not reduced.

Gas: Negative.

\section{Bacillus F'lourescens liquefaciens.}

Diameter: I,ess than 1 micron.

Spores: Io spores could be found.

Notility: Positive.

Gram: Negative.

Broth: Sediment-broth assumes Ereen color.

Agar: Iuxuriant growth - agar is turned green.

Gelatin plates: Gelatin rapidly liquefied. Greenish color.

Potato: Scant dark colored Erowth.

Milk: Coagulated and casein is digested.

Indol: Slightly positive.

Nitrates: Ammonia is produced.

Gas: No gas is formed. 

Conclusions. Neither of these forms are of any sanitary aignificance. Bacillus subtilis is a form abundant on grass. Bacillus floresceus liquefacieus is a comon water form. Semple B

The source of this water was a $90^{\prime}$ drilled well. The casing is sunk thru rock and clay and the water is pumped from the rock by an iron pump. Since the cover is of cement and watertight, no surface water can get into the well. The number of bacteria on agar was 7 and on gelatin, 67. The chemical analysis showed a normal water for such a source. The tests for Bacillus colon were negative. The oolonies on gelatin were evenly distributed and had begun to liquefy the gelatin in less than 43 hours.

\section{Bacillus Vulgatus.}

Diameter: Less than 1 micron. Spores: Negative. Hotility: Positive. Gram: Positive with pellicle. Broth: Turbid with pelifolo. Agar: White. Gelatin plates: Round liquefyers. Potato: Scanty growth. Milk: Coagulated. Partial digestion of casein. Indol: Posttive. Nitrates: Gas: Negative. 

Conclusions. Bacillus vulgatus has no sanitary significance. It is a rather common form.

Sample C

The source of this sample was a $2500^{\prime}$ well. The casing was put down thru rock and sandstone and had been pumped for a long time. The count on agar was 30 and on gelatin, 6. Iarge liquefying colonies of a flouresoent green were present as in many of the deep well waters. The colony ploked off had the following characteristic.

\section{B. arborescens.}

Diameter: Slender motile rod.

Spores: Negative.

Motility: Positive.

Gram: Negative.

Broth:

Agar: Yellowish.

Gelatin plates: Rapid liquefyer - Dark opaque colonies with hairy projections.

Potato: Orange colored growth.

Mili: No change.

Indol: Negative.

IItrates: Ređuced.

Gas: ITo gas.

Conclusions. Bacillus arborescens is found in soil. This might explain its presence in a water.

Sample D

A well drilled in drift $1135^{\circ}$ furnished this water. 

The well is cased with iron pipe and has a water tight cement cover. No feed lot, privy or stable is near the well. The gelatin plates were covered with liquifiers which made large saucer-like depressions in the medium. From this sample of water the following organism was isolated.

\section{Bacillus mycoldes.}

Diameter: Large bacillus.

Spores: Positive.

Motility: Positive.

Gram: Positive.

Broth: Cloudy with pellicle.

Agar: White growth irregular edge, after spreading.

Gelatine plates: White with many branches.

Potato: Thite. No discoloration.

Indol: Negative.

Nitrates: Reduced to nitrites and amonia.

Gas: Negative.

Conclusions. Bacillus mycoides is a common species of bacteria and might easily get into a water.

In all the above cases, it is realized that these different possibilities allowing bacteria to get into a ground water. The well might be a new one which was not thoroly flushed out when the sample was taken. Or, it might have a bad casing allowing surface water to enter.

Since bacteria have been reported in deep wells 

from different parts of the world, it seems probable that certain foms do live in deep well waters.

\section{PART I. (B)}

Bacilius Colon in Ground Waters.

The presence of Bacillus colon in a water has been accepted by most sanitarians as a sufficient indication that the water has, in some way, received sewage pollution.

Bacillus colon was discovered in 1885 by Emerich while working on the feces from cholera patients. Since it was found to be present in such large numbers, in that part of the intestine termed the colon, it was given the name Colon Bacillus. When it was first discovered, it was thot to be an inhabitant only of the human intestine. This theory, however, was very soon to be disproved. Flint 5 worked on the feces from the animals in the Chicago Zoological Garden. He found Bacillus colon in the excreta from the snake, Ilama, white rat, bear and a few others. He concluded that Bacillus colon was not a sufficient basis on which to condemn a water. Belitzer ${ }^{6}$ and Dyer and Keith ${ }^{7 a_{0}}$ obtained results to the same effect that Bacillus colon was not only present in the human intestine, but rather widel 7 istributed thru the intestines of most warm blooded animals. Much other work has been reported by various men on Bacilius colon and Its ubiquity in warm blooded animals.

Numerous instances are cited of its occurrence in the cold blooded animals. Amyot ${ }^{22}$ tried to prove the pres- 

ence of Bacillus colon in fish. He could not find it in twenty-three fish, including fourteen varieties. Johnson ${ }^{24}$ examined sixty different fishes from the IIlinois and Mississippi rivers. He succeedod in isolating Bacillus colon from forty-seven. In forty-one of these the organism was isolated from the intestine. He cites the carrying of Bacillus colon by fish as a method by which a pure water could be apparently polluted. As mentioned before, Flint proved it in the snake. Moore and Wright ${ }^{25}$ could not find it in the frog. Eyre 26 reports its presence in the fish and also in some warm blooded animals.

Prescott ${ }^{7 b}$ found an organism similar in all characteristics to Bacillus colon on grains from fields where animal contact was improbable. Even in this case will arise the possibility of birds distributing Bacilli Coli over such areas. One of Prescott's conclusions was that care should be used in interpreting an analysis of a water where Bacillus colon was found to be present.

Metcalf ${ }^{8}$ reports Bacillus colon on some South Carolina rice fields.

Smith ${ }^{9}$ found colon like bacteria on a field of rye in western Massachusetts.

Since colon organisms heve been found in so many different places, even where animal contact was improbable, the question can be raised whether its presence can be taken as an accurate indication of pollution. If it has as wide 

spread distribution as it seems to have, it is easy to imagine how it might grin access to a safe potable water. Prescott has indirectl proposed in one of his publications that this organism might originally have been a plant form, and finding the intestine of animals such a favorable abode, had taken up its habitation there.

In $1894 \mathrm{Kruse}^{10}$ in a paper in which no experimental date is given, advised against the use of this organism, as an indication of pollution. He said that we were dealing with a group of bacteria and not a single organism. Since it was found in the air, water, and earth, he believed it could not be taken as a sufficient indication of pollution. Beckman $^{11}$ found Bacillus colon in the city supply of strassburg. This water is taken from deep wells. In his work, he used large quantities.

Maroni $1^{12}$ after examining some deep and shallow wells about Parma concluded that $B$. colon had no sanitary significance.

Weissenfeld ${ }^{13}$ like Kruse stated Bacillus colon could be found in all waters if large enough quantities were taken. During his work, he studied about thirty samples of a supposedly good water.

on the other hand, we have those who contend that no good water should contain Bacilli coll. Chick ${ }^{14}$ has this view. Sarage ${ }^{2}$ states that sufficient evidence has not yet been produced to discard Bacillus colon as an indication of 

pollution. The same statement has been made by Moore.

\section{BACIIUUS COLON IN DEEP WEIIS}

That we should find any indication of pollution in a ground water is queer, but since bacteria have such a wide distribution, it is possible. Many instances are given of contamination of under ground waters.

\section{Harton ${ }^{15}$ in examining deep well and spring waters} in Ohio often met with organisms resembling Bacillus colon. All shallow wells were excluded and only those vells which were cased, were considered. Bacillus colon was found twice at an interval of a month. The chemical data showed no pollution. Horton concluded that (I) Bacillus colon in ground water should condemn them and (2) the fact that water may come from underground sources should not be a guarantee of its purity•

Nankivell ${ }^{16}$ points out that water from wells in chalk are liable to intermittent pollution and should be purified. Microo"rganisms may get into the water thru fissures and swallow holes from many miles distant, to infect an apparently pure water supply.

Ihresh, in his book on water supplies, quotes many instances of finding Bacillus colon in deep well waters. He says, "There are few if any waters in which Bacillus colon cannot be found if a sufficient quantity is taken."

The following work was done on a series of nineteen tubular wells, constituting the supply for a city of about 

eleven thousand inhabitants. The positive test for gas formation varied in the water, but were usually present in $1 \mathrm{cc}$. samples. These wells vary from $80^{\prime}$ to $125^{\prime}$ in depth. They are all connected to the same pump suction so that it is impossible to secure a sample of water from any one vell to see which one is furnishing the gas formers. Water is taken from the gravel deposits of a nearby river. page $\mathrm{No}$. 16 the following table/shows both the chemical and bacterial analyses of the water from June 25, 1906 - May, 1914. It shows a variation in quality which may be due to the intermittent entrance of another kind of water. The chlorine which is a valuable constituent by which to judge the quality of a water varies between 61 and $35 \mathrm{p} \cdot \mathrm{p} . \mathrm{m}$. Similar variations can be seen in the residue, oxygen consumed and nitrogen content. The number of bacteria is not excessive, but the almost constant presence of gas formers is a bad indication.

These wells are locatea near a large river carrying a very highly polluted water. The drainage from the surrounding country is towards the river, since the land slopes gradually away from it. No observations had ever been made to deternine the direction in which the ground water moved. The soil is of sand and gravel. There is no impervious stratum to protect the ground water from the surface water which might get in.

Since the soil is so sandy, we may assume that 

there is more or less in filtration of surface water. Te can hardly assume that the same standard of purity vould be secured here as would be the case with a sand filter. There would not be a proper rate of filtration nor a satisfactory arrangement of sand and gravel to secure the highest efficiency. 0ld wells, fissures and cess pools might allow polluted water to get into the water bearing stratum with insufficient purification.

There is a possibility of some underground connections with the badly polluted river. Ihe following table has been prepared to show the relation of the constituents of the river water, the city water and water from two wells and of about the same depth, located within a half a block of the city wells. 

River City Wells Private Private WeII

No.1 No.2

Iaboratory No.

27414

27416

27261

27262

Date

Turbidity

Color

odor

Residue

Chlorine

Oxygen Consumed

Nitrogen as

Free Ammonia

Alb. Ammonia

Nitrates

Nitrites

Alkalinity

Bacteria per cc.

$$
\text { Agar }
$$

Gelatin

Gas Formation

$10 \mathrm{cc}$.

$1 \mathrm{cc}$.

$0.1 \mathrm{cc}$.

$.01 \mathrm{cc}$.
$4 / 20 / ' 14 \quad 4 / 20 / / 14$

50

30

$2 c$

332

13.6

7.3

3.520

3.200

2.64

.030

154.0

16,000

50

80

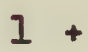

$1+$

2 -

$2+$

2 -

$2+$
0

0

$1 \nabla$

498

42 .

. .5

.024

.000

.000

7.20

274.

$3 / 28 / ' 143 / 28 /$ ' 14

2

0

0

0

10

10

357

617

10

14

1.6

1.5

.000

.000

.004

.000

7.20

13.20

246.

264.

8

1

$\begin{array}{ll}1 & 1\end{array}$



- торur

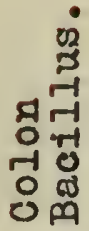

$.00[\cdot 0$

d 1 i

方

11

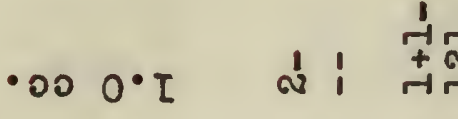

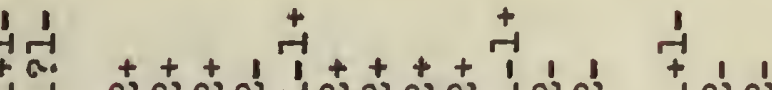

- 000

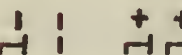

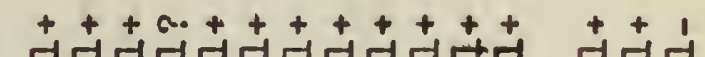

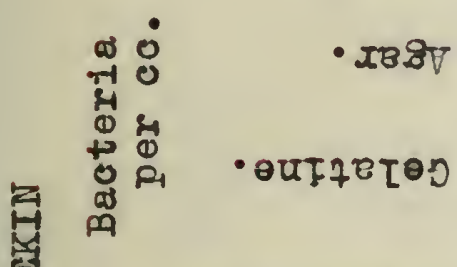

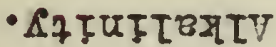

I

i

1 i i i i : i i i :

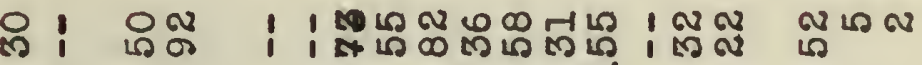

a

$\dot{0} \dot{0} \dot{\infty} \dot{\infty}, 1, \dot{\infty} \dot{\infty} \dot{0} \dot{0} \dot{0} \dot{0} \dot{0}$

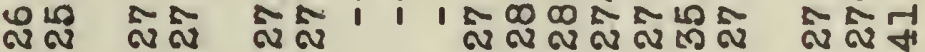

.

- se78x7fR

$\infty$

$\infty$

- sə7 Txz fII

9

- $p$ țo

点

$\underset{1}{1}$

荘

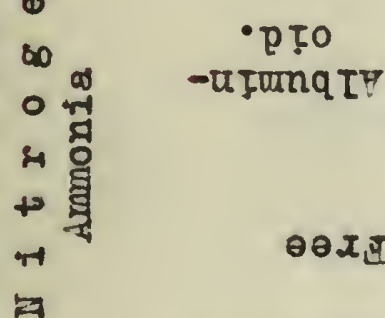

- poumsuop

पQ8AxO

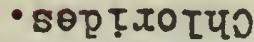

पद़ बपनร०โप०

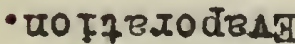

to enp rsed

व

- zopo

- IOTOD

- \&7fpfquñ

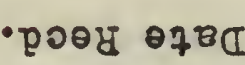

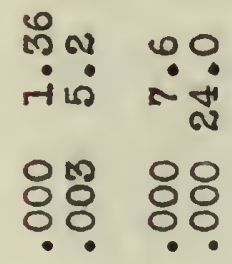

0000000

000

$\cdot \bullet$

울

$1.0 \cdot 0 \cdot 1$.

ar 2

뉴

\%.

응ㅇㅇ I I I

ㄷํㅇㅇㅇㅇㅇㅇ

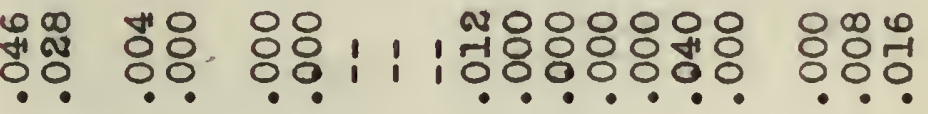

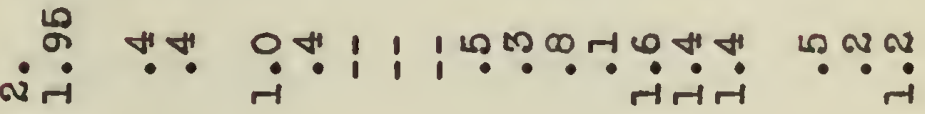

เ

$+\infty$

$\infty$

$\dot{\omega}$

ம0ON

이 1 , I

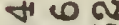

N 000

ต

$\dot{0} \dot{0} \dot{0}$

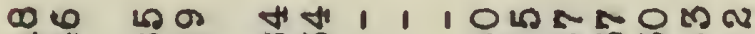

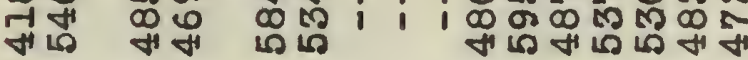

동

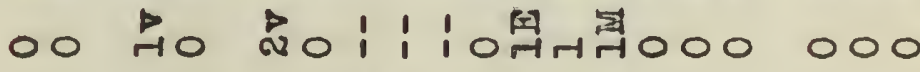

L

เ

$000000 ; 1 ; 0000000000$

00 no 00 !'!l 10000000 w00

L पूरत नी की "

$+\infty$ क

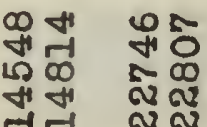

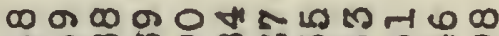

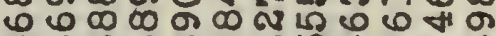

$\infty \infty \infty \infty \infty \pi)$

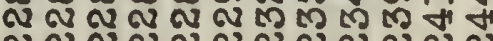

$+\infty \mathrm{dr}$

- 00

$\infty-\infty$

सम 


The analytical results show a decided difference between the river water and that taken from the wells. Pollution from this source is improbable, altho a small amount of river water might account for the variation in the city well water.

Gas forming bacteria have been present in $10 \mathrm{cc}$. samples of the water in over 90 per cent. of the analyses made. The I cc. samples are positive in nearly 50 per cent. of the samples analyzed. In the 0.1 cc. samples a much better showing is made with only 9 positive tests from 64 . At six different times, gas formers were isolated and found to have oharacteristics agreeing with Bacillus colon. Very rarely were there any liquefyine bacteria present, but flourescent colonies quite often appeared. Some of these proved to Bacillus flourescens liquifacieus and Bacillus flourescens non-liquefacieus, as indicated below.

\section{ISOIATION OF BACTERIA}

The methods of isolation were those commonly used and recommended by the Society of umerican Bacteriologists. The sarples of water sent to the state Hater Survey are packed in ice. Some of the samples which were stuaied were taken by representatives of the state Water Survey, by which means, we hoped to eliminate the daneer of contamination by having inexperienced men take the samples. When the sample was brought to the laboratory it was plated on litrus lactose agar, plain agar and plain gelatin. The red colonies devel- 

oping on litmus lactose agar were picked off and purified by the usual methods.

Confirmatory tests were made according to the chart of the Sooiety of Amerioan Bacteriologists. In addition, Endo's medium and Russell's medium was used. Both of these special media gave reaotions characteristic of Bacillus colon.

The following charaoterlsitics were assumed to be typioal of Bacillus colon:

Shape: Baciliug $2-3$ microns X .5 micron. Motility: Motile with flagella. Spore: Negative.

Gram: Positive.

Gelatin colonies: Small, thin colonies. No liquefaction. Gelatin stab: Thin growth more vigorous at the surface. Agar stab: Very soanty growth.

Agar stant: Thick growth.

Iftmus milk: Acio and ooagulation after a few days. Indol: Present after 3 àys at $37^{\circ} \mathrm{C}$.

Potato: Brown growth. Nitrate: Roduced.

Iactose: Fermented giving gas and acid. Dextrose: Fermented fiving gas and acid. Laccharose: Fermented fiving usually gas and aold. The chart giving the characters of the gas former isolated from the deep wells, is attached. Characters were not always constant. The motility varied somewhat, but gas formation was congtant. The organism from the deep wells 

has characters identical with those of Bacilius colon. In this case the bacteriologioal analysis is more delicate than the sanitary chemical.

\section{Attermpt to Irace Source of Pollution.}

Realizing that olight contamination was possible

from these wells, salt was used as a means of trying to determine the source of pollution.

Different methods have been used to trace pollution of underground waters; chief among these have been salt, lithium salts, flourescein and bacterial suspensions such as Bacillus prodigiosus.

Salt has been used in many instances for such purposes. HacCollie ${ }^{17}$ used this method to demonstrate to the citizens of Georgia the results which would be obtained, were a deep well used to dispose of sewage. It was found that a 124' drilled well would carry awry an unlimited supply of water and it was proposed to use this as a method of disposing of the sewage. A large amount of salt was put down the well and the chlorine content of the surrounding wells watched. The ohlorine increased in the wells and springs in the vicinity, showing that there was underground connection with each well and spring. This demonstrated. what would have resulted, had the well been used to carry away the sewage.

Dole 18 in a paper on the use of flourescein in tracing water courses, comes to the following conclusions: 

(1) In studying the sanitary character of a well, it is more valuable to study the underground flow then to analyze the water itself.

(2) Foreign substances put into an aquifer and traced from point to point, aro of great value in this studj.

(3) With the flourescope 1 pt. of flourescein in 10 billion pts. of water can be detected.

(4) Flourescein is a particularly valuable flow indicator for fissured and cavernized rooks.

(5) It progresses at a slightly slower rate than the water in which it is suspended.

(6) It is not decolorized by passage thru sand, gravel manure; it is slightly decomposed by calcareous soils.

(8) It is entirely decolorized by peaty formations and by free acids except by carbonic acid. These conclusions give the limitations of this chemical in tracing ground waters.

M. Prillat ${ }^{19}$ has used many colored substances to trace motion of underground waters and claims that flourescein can be detected in ailutions of He claims that before this dye is used in this capacity, a study of the solls should be made to determine the presence of any matters which might decompose the dye. Marboutin, $F^{20}$ gives an account of this aye when used to trace underground waters and comes to about the same conclusions that others have. Martel ${ }^{21}$ shows that this dye even in very concen- 

trated solutions decolorlzes rather quickly when kept in the sunlight. When it is kept in complete darkness, which would be the case in the earth, it did not change even after long periods of time.

Gehrmann ${ }^{22}$ reports some work of Alba Orlandi and Roudelli, who used a suspension of Baclllus prodigrosus. They found that this organism found its way thru soil two hundred meters, when poured on the ground. In the same paper is quoted the work of Pfulil, who found that it took the same organism a short time to pass thru twenty-four feet of gravel. Gehrmann also reports an instance, coming under his own observation, where wells two to three hundred feet deep located too neer an old canal were subject to entrance of contaminated water. No experimental data is given in this paper.

In the weIls on which this work was done, it was thot best not to use flourescein on acoount of the possibility of coloring the water too much. Since these wells furnish the only supply for a city of 9897 inhabitants, and since it is difficult to remove this chemical effectively under ordinary conditions, salt was used in an attempt to see if there was any seepage from the surface.

One ton of fine salt was evenly divided between eleven privy vaults. This was placed in them on the same afternoon, the chlorine content of the water having been previously determined. The plot shoring the locetion of these privys with respect to the water works is given. 


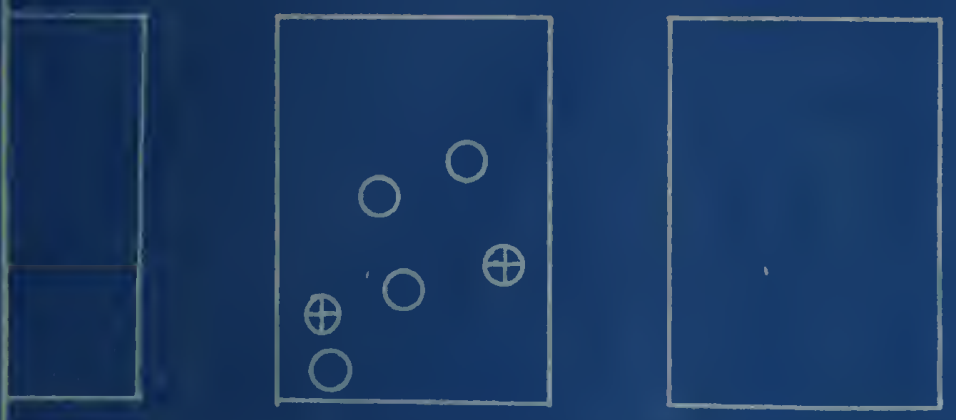

City Water Workst

0

\section{O}

- Privy vaults in which satt wasplaced.

- Wells sampled.

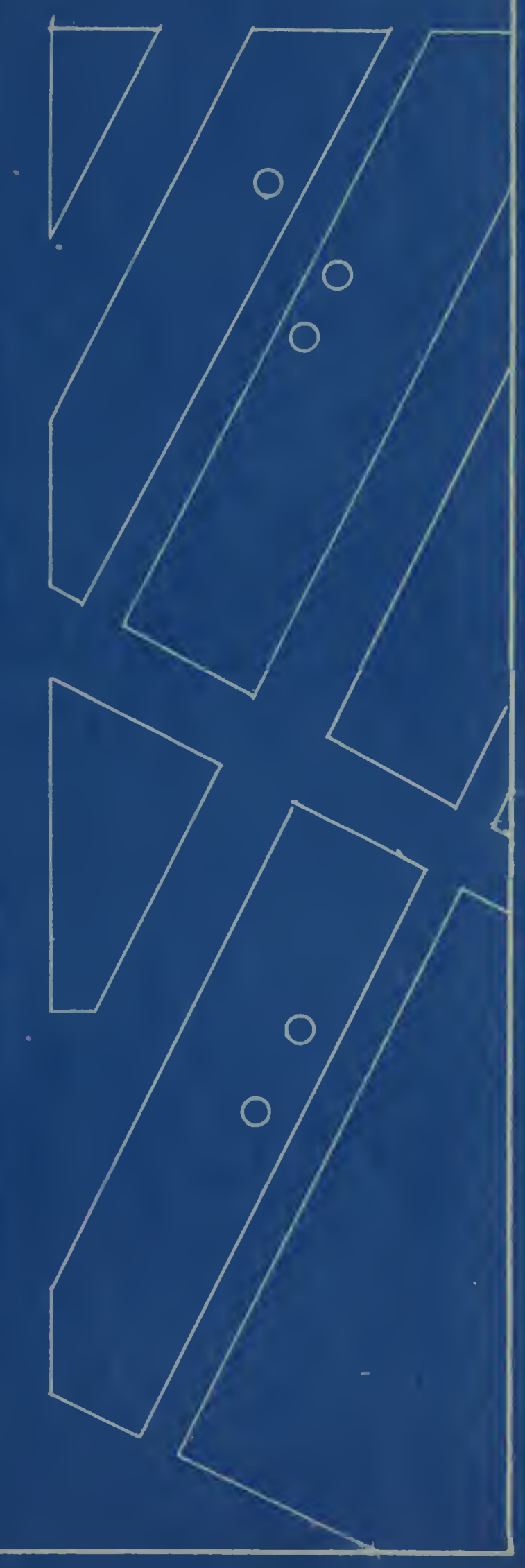



When this experiment was sterted the chlorine content was 42 pts. per mil. From the table it will be seen that this changed scarcely at all. 



\begin{tabular}{|c|c|c|c|c|c|c|}
\hline \multicolumn{2}{|c|}{ Date } & Prom & To & $\mathrm{CC}$ & $P \cdot P \cdot M$. & Remarks. \\
\hline March & 16 & 22.5 & 26.7 & 4.2 & 42 & No salt. \\
\hline " & 17 & 22.5 & 26.9 & 4.4 & 44 & Salt added. \\
\hline$"$ & 17 & 21. & $25 \cdot 3$ & $4 \cdot 3$ & 43 & \\
\hline$"$ & 18 & 21.6 & 26 & 4.4 & 44 & \\
\hline$\|$ & 18 & 22 & 26.5 & 4.5 & 45 & \\
\hline$"$ & 19 & 21. & 25.3 & 4.3 & 43 & \\
\hline * & 19 & 21.7 & 26.1 & $4 \cdot 4$ & 44 & 10 gals. water ada- \\
\hline$n$ & 20 & 21.6 & 26.1 & 4.5 & 45 & ea to all vaults. \\
\hline 18 & 20 & $21 \cdot 8$ & $26 \cdot 2$ & 4.4 & 44 & \\
\hline$"$ & 21 & 22.8 & $27 \cdot 2$ & $4 \cdot 4$ & 44 & \\
\hline$n$ & 21 & 21.5 & 26 & $4 \cdot 5$ & 45 & \\
\hline$n$ & 23 & 18.5 & 22.8 & 4.3 & 43 & \\
\hline$n$ & 23 & 20.5 & 24.8 & 4.3 & 43 & \\
\hline$"$ & 24 & 19. & 23.4 & 4.4 & 44 & \\
\hline$n$ & 24 & 19. & 23.3 & $4 \cdot 3$ & 43 & \\
\hline$"$ & 25 & 22 & 26.2 & $4 \cdot 2$ & 42 & \\
\hline " & 25 & 22.5 & 26.8 & 4.3 & 43 & \\
\hline$n$ & 26 & 20.5 & 24.7 & 4.2 & 42 & \\
\hline$"$ & 26 & 20 & 24.2 & $4 \cdot 2$ & 42 & \\
\hline$"$ & 27 & 21. & 25.2 & 4.2 & 42 & Heavy rain night of \\
\hline * & 27 & $24 \cdot 5$ & 28.8 & $4 \cdot 3$ & 43 & $3 / 26$ \\
\hline$"$ & 28 & 21.5 & 25.8 & 4.3 & 43 & \\
\hline " & 28 & 20.5 & 24.7 & $4 \cdot 2$ & 42 & \\
\hline$"$ & 30 & 21.5 & 25.8 & $4 \cdot 3$ & 43 & Heavy rain night of \\
\hline t & 30 & 21 & $25 \cdot 2$ & $4 \cdot 2$ & 42 & $3 / 29$ \\
\hline$\pi$ & 31 & 20.5 & 24.7 & $4 \cdot 2$ & 42 & \\
\hline$n$ & 31 & 20.5 & 24.7 & $4 \cdot 2$ & 42 & \\
\hline Apr 11 & 1 & 20.5 & $24 \cdot 7$ & $4 \cdot 2$ & 42 & Heavy rain night of \\
\hline$n$ & 2 & 21. & 25.2 & $4 \cdot 2$ & 42 & $3 / 31$ \\
\hline$n$ & 3 & 21. & $25 \cdot 2$ & $4 \cdot 2$ & 42 & \\
\hline 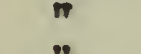 & 4 & 22.5 & 26.8 & $4 \cdot 3$ & 43 & \\
\hline$"$ & 6 & 21.5 & 25.8 & 4.3 & 43 & All day rain from \\
\hline$n$ & 7 & 22 & $26 \cdot 2$ & 4.2 & 42 & 6:00 A.II \\
\hline$"$ & 8 & 22. & $26 \cdot 2$ & $4 \cdot 2$ & 42 & \\
\hline$"$ & 9 & 21.5 & 25.7 & $4 \cdot 2$ & 42 & \\
\hline$n$ & 10 & 23 & $27 \cdot 2$ & 4.2 & 42 & 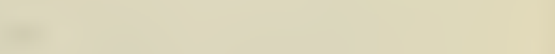 \\
\hline$"$ & 11 & 22. & $26 \cdot 3$ & 4.3 & 43 & \\
\hline$n$ & 13 & 23. & $27 \cdot 2$ & $4 \cdot 2$ & 42 & \\
\hline$"$ & 14 & 22. & $26 \cdot 2$ & $4 \cdot 2$ & 42 & \\
\hline$"$ & 15 & 20. & $24 \cdot 2$ & $4 \cdot 2$ & 42 & \\
\hline$"$ & 16 & 20.5 & $24 \cdot 6$ & 4.1 & 41 & \\
\hline$"$ & 17 & 22.5 & 26.6 & 4.1 & 41 & \\
\hline$"$ & 18 & 22.5 & 26.6 & 4.1 & 41 & Pumped for fire 2 hrs. \\
\hline$"$ & 20 & 22.5 & $26 \cdot 5$ & 4. & 40 & sample taken 45 min \\
\hline$"$ & 23 & 2द. & $26 \cdot 1$ & 4.1 & 41 & after fire out. \\
\hline$"$ & 25 & 20 & 24.1 & $4 \cdot 1$ & 41 & \\
\hline
\end{tabular}



Since there was no increase in the chlorine content, it is quite apparent that there is no direct connection with pollution from surface sources.

\section{PART II.}

\section{Surface Waters.}

At one of the large filtration plents on the IIssissippl river two kinds of bacteria have been troublesome. Brief Description of Filter Plant. The plant is of the rapid sand type furnishing about $4,000,000$ gallons of water per day. The water is taken from the Mississippi river and has a normal chemical content for that water. The raw water is coagulated with alun, filtered and disinfected with calcium hypochlorite.

On the plates made from the sterilized water, large Ifquifiers were quite numerous. On the raw water these colonies were also present, but since a higher dilution was used, they were not so numerous.

Plates of the treated water have at times contained thousands of small colonies. These have made their appearance periodically. They are described later by chart.

A few of the monthly analyses and the average reduction in bacteria are shown in the following table: 



\begin{tabular}{|c|c|c|c|c|c|c|c|}
\hline \multirow{2}{*}{\multicolumn{2}{|c|}{$\begin{array}{l}\text { DATE } \\
1913\end{array}$}} & R A & W & \multicolumn{2}{|c|}{ STERIIIIZED } & \multirow{2}{*}{$\begin{array}{l}\text { GEIITR AI } \\
\text { Agar }\end{array}$} & \multirow{2}{*}{$\begin{array}{l}\text { EFIUENT } \\
\text { Gelatin }\end{array}$} \\
\hline & & Ager & Gelatin & Agar & Gelatin & & \\
\hline Jan. & & 770 & 2600 & 10 & 85 & 6 & 116 \\
\hline $\mathrm{E} \in \mathrm{b}$. & & 740 & 2200 & 47 & 60 & 12 & 340 \\
\hline March & 3 & 70 & 5500 & 20 & 7000 & 5 & 17 \\
\hline Nar ch & 23 & 680 & 82000 & 162 & 1240 & 6 & 7 \\
\hline April & 11 & 530 & 6500 & 90 & 155 & 0 & 0 \\
\hline Hay & 3 & 340 & 2600 & 43 & 760 & 6 & 440 \\
\hline May & 12 & 1700 & 3800 & 35 & 36 & 3 & 25 \\
\hline JuIy & 1 & 233 & 50000 & 800 & 7400 & 9700 & 3000 \\
\hline JuIy & 14 & 1200 & 1200 & 33 & 65 & 34 & 89 \\
\hline Aug. & & 1500 & 6900 & 250 & 220 & 97 & 96 \\
\hline Sept. & & 1250 & 3000 & 114 & 300 & 210 & 60 \\
\hline oct. & & 310 & 7600 & 76 & 260 & 45 & 80 \\
\hline Dee. 3 & & 1600 & 5100 & 325 & 550 & 70 & 63 \\
\hline $\begin{array}{r}\text { Dec. } 3 \\
1914\end{array}$ & & 86 & 430 & 36 & 35 & 1 & 2 \\
\hline Jan. & & 320 & 3600 & 43 & 52 & 4 & 10 \\
\hline Feb. & & 130 & 640 & 55 & 110 & 2 & 2 \\
\hline
\end{tabular}

These analyses show the effect of treatment on the bacteria content. The presence of large liquefiers often made counting difficult. This was often the case before the plates had been incubated fifteen hours. After isolating them from several different samples, they were found to be Bacillus flourescens liquefacieus. Thia organism is present in most waters, both those on the surface and those from the ground. 

It was noticed here as in other cases that where liquefiers were present on gelation that the agar colonies would spread making accurate counting diffioult.

Just how these bacteria get into the treated water is difficult to say. Apparently, all are not killed by hypochlorite. They may develop in some way in a part of the plant after the water has been filtered.

The following table gives results which were obtained by treating the strain with hypochlorite. The counts were made from agar incubated at $37^{\circ} \mathrm{C}$.

$\begin{array}{ccc}\begin{array}{c}\text { Available chlorine } \\ (\text { pts.per mil) }\end{array} & \text { Untreated } & \text { Treat } \\ .0 & 121 & 118 \\ .1 & 170 & 170 \\ .2 & 98 & 105 \\ .4 & 120 & 116 \\ .6 & 230 & 225 \\ .8 & 60 & 75 \\ 1.0 & 200 & 190 \\ 1.2 & 175 & 100 \\ 1.4 & 150 & 130\end{array}$

The results show that this strain is not affected. by calcium hypochlorite. Filtration does not entirely remove them for they are found in the sterilized water and in the general effluent. They have no sanitary significance and so can be looked on merely as peculiarities of this water.' 

On the same water there developes at times thousands of minute colonies. These grow slowly at $20^{\circ} \mathrm{C}$ on gelatin. When these appeared on the gelatin plates colonies were taken off and put on agar slants. After the culture was purified, the characteristics were determined on the standard media. The attached chart shows them. This organism is not a gas form and so is not a momber of the colon group. According to ligula's classification it has the characteristics of Hicrococcus candicans. 



\section{Source Pekin Well Water. Date of Isolation}

\section{DETAILED FEATURES.}

NoTE--Enderscore required terms. Observe notes and glossary of terms on opposite side of card.

1. MORPHOLOGY (2)

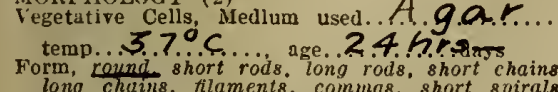
long chains, filaments, commas, short spirals.
long spirals, clostridium, cuneate. clavate. curved.
Limits of Size. $/ \mu . X .8 .8 \mu$

Slze of Majority..............

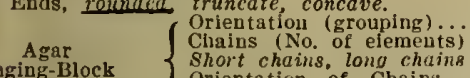

Banging-Block $\quad\left\{\begin{array}{l}\text { Agar } \\ \text { Short chains o lang chiting } \\ \text { Orientation of Chains, parallel }\end{array}\right.$

2. Sporangia, medium used...........temp.......... age......ilipticalass
rormort rods, spindled, clavate.
drumstichs Llmits of Size........ Size of Majority........ Agar $\quad\left\{\begin{array}{l}\text { Orlentation (grouping) } \\ \text { Chains (No. of elements) } \\ \text { Orreger. }\end{array}\right.$

Banglng. Bloek $\quad\left\{\begin{array}{l}\text { Chains } \\ \text { Orieutation of Chains. paralleil } \\ \text { irregallor }\end{array}\right.$ Location of Endospores, central, polar.

Eindospores.
Fiorm, round, elliptical, elongated.

Linilts of Slze..........

Size of Majority.

Sporangium wall, adherent, not adhcrent.
Germinuatlou, equatorial, oblique, polar, bipolar. by stretching. Atachent polar, bipolar, per-
Flagella No....... itrichiate. How Stained............

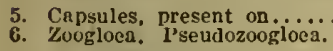

7. Involution Forms, on ........in ...days at ... ${ }^{\circ} \mathrm{C}$.

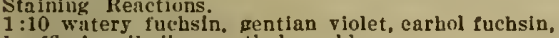
Lefficr's alkaitue methylene blue.

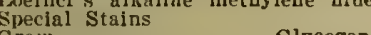

Fat ................. Acld fast ..............

Neisser.

11. CULTURAL FEATURES (3)

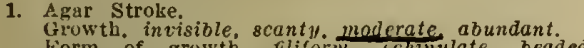
orm of growth. filicoput cchmulate, beaded.

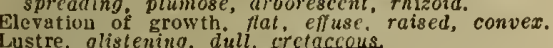

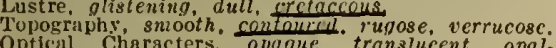
cescent, iridescent
Chromogeuesis (8)

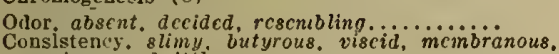
Consistency.y. slimy.
coriaccous brittie. Mcclium grayed, browncd, rcddened, blued, oreened. Growtith. scanty, moderate, abundant, transient. Form of growth, flitorm. cchinulate. beaded. sarceding plumose, arborsecent. Thizoid.

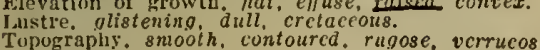
Chromogenesis $(8) \ldots \ldots \ldots$. Pigment ln water insoluble, soluble; other solvents............. Odor absent, decided. resembling $\ldots \ldots \ldots \ldots \ldots \ldots$.
Consistency, slimy. butyrous, viscid, membranous, coriaceous, brittile
Mediun, graved. proined reddencd, blued, greencd. Stroke incisible, sccinty, moderate abundant.
Form of prowth fliliorm echinulate. beaded. Form of growth, fililorm, echinulate, beaded.
spreading. plumose, arborescent, rlizoid.

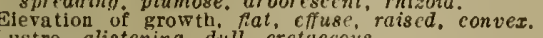

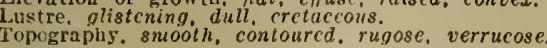
Chromogcnesls
Medium grayed.

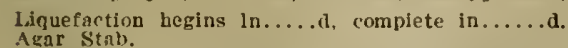

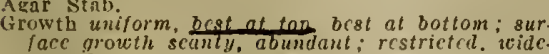
Line of puncture. wibarm beadcd. panillate, vil.
5. Gelatin Stah.

Growth
Line of inform,
lous lous, pluniose, arborescent.
Liquefaction, crateriform, napiform. infundibuliform. saccate, stratiform; begins in.........d, complete in $\ldots \ldots \ldots$ d.
Medium
fuorescent,

6. Nutrient Broth. Surface growth, ring, pellicle, nocculent, mem-

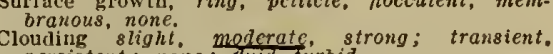

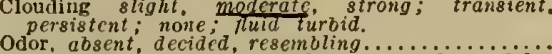

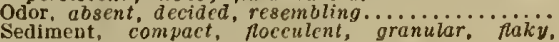
Sediment, compact, Rocculent, grantidar,

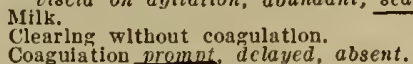

Extruslon of whey hegins ln.........dars. Peptonizatlon begins on....d, complete on..... Peptonizatlon begins on.....d, complete on.....

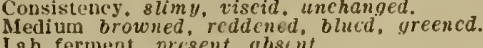

prisent, absint.

Acid alkalinic acid then alkaline, no change.
Prompt reducion no reduction, partial slow re. Gelactin Colouies.

Growth, slow rapid.

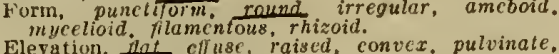

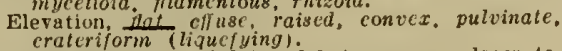
Edrateriform (liqueryingl iobate, erose, lacerate.

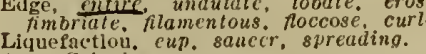

10. Agar Colonies.
Growth slow, ranid, temperature.. $3.9 .9 \mathrm{C}$.

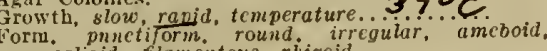
myjeelioid, filamentorts, rhizoid.
Surface smoath, rough, concentrically ringed, radi-

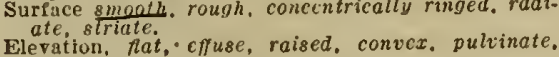
Edge. cnitire, undulate, lobate, crose, lacerate. fimibriate.
Internal seose, curled.
structure, anorpho, finely-, coarselygrunular, grumose, nlamentous, foccose, curled. Girowth, scanty, copious.
Diastasic action, absent, feeble, profound.

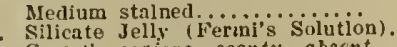

Growth copious, scanty, abscht.

Medium stained

Gromith, copious. scanty, absent.

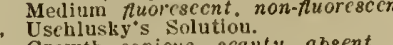

Growth eopious, scainty, absent.

15. Sodtum Chlorite $\ln$ Biscia. Boullon.

16. Prowth in Bouilon over chiloroform, unre-

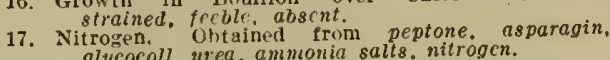

18. Best medis for lony. continued growt th.........

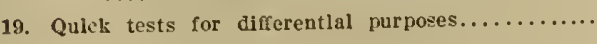

\section{PHYSICAL AND BIOCHEMICAL FEATURES.}

Fermentation-Tubes con-
taining peptone-water or

taining peptone-water or 0

Gas production, in per cent.

$$
\left(\frac{\mathrm{H}}{\mathrm{CO}_{2}}\right)
$$

Gmount of acid produced d d.

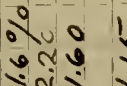

\section{Bacillus Colon, aroup No. (1)}

2. Ammonia production, feeble, moderate, strong. absent, masked by acids.

3. Nitrate in nltrate broth,

Reduced, not reduced.

Presence of nitrites.

ammonia....

"nitrates........ free nitrogen.

. Toleration or Acids tcoted.

6. Toleration of NaOH: Great, medium, slight.

7. Optimum reaction for growth in boullon,

8. Vitality on culture media: brief, moderate, long. Temperature relations

Thermal deatb-point (10 minutes exposure 1n nutrient hroth when this is adapted to growth of organism).

Optimum temperature for growth......... : or best growtb at $15^{\circ} \mathrm{C}, 20^{\circ} \mathrm{C}, 25^{\circ}$ C, $30^{\circ} \mathrm{C}$ C. $400^{\circ} \mathrm{C}, 500 \mathrm{C}$, 500 Maximum temperature for growth......... Mlnimum temperature for growth.........

10. Kllled readlly by drying: resistant to drylng.
11. Per cent klled by freezing (salt and crushed ice or liquid air).

12. Sunllght: Exposure on ice in thlnly sown agar plates: one-half plate covered (time $15 \mathrm{~min}$ utes), scusitive, not scnsitive.

Per cent killed.

13. Acids produecd

14. Alkalies produced

15. Alcobols

Fernents ; pepsin, trypsin, diastase, invertase, pectase, cylase, tyrosinase, oxidase, peroxidase. lipase, catalase, glucase, galactase, lab, etc....

17. Crsstals formed:

19. Effect of germicides:

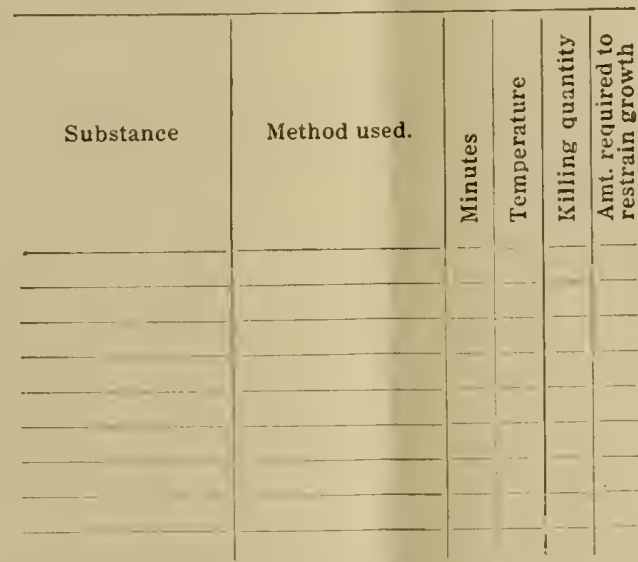

IV. PATHOGENICITY.

1. Pathogenic to Animals

Insects, crustaceans, fishes, reptiles, birds, mice, rats, guinea piss, rabbits, dogs, cats, sheep, goats, cattle, horses, $m$

2. Pathogenic to Plants:

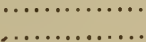

3. Toxins, soluble, cridoto

4. Nori-toxin forming.

5. Inmunity bactericidal

6. Immunity non-bactericidal.

7. Loss of virulence on culture media: promp gradual, not observed in
BRIEF CHARACTERIZATION Mark + or $O$, and when two terms does not apply unless both apply.

Diameter over $1 / \mu$

Chains, filament

Endospores

Capsules

Zoogloea, Pseudozoogloea

Motile

त् Involution forms

Gram's Stain

Cloudy, turpid

Ring

Pellicle

Shining

Dull

Wrinkled

Chromogenic

Round

P Proteus-lik

Rhizoid

Filamentous

Curled

Surface-growth

Needle-growth

Moderate,

Abundant

Discolored

Starch destroyed

Grows at $37^{\circ} \mathrm{C}$.

Grows, in Cohn's Sol.

Grows in Uschinsky's Sol

F. Gelatin (4)

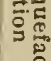

Blood-serum

Agar, mannan

Acid curd

3 Rennet curd

Casein peptozized

Indoì (5)

Hydrogen sulphide

Anmonia (5)

Nitrates reduced (5)

Fluorescen

Luminous

Animal pathogen, epizoon

Plant pathogen, epiphyte Soil

Milk

Fresh water

Salt water

Sewage

Iron bacterium

Sulphur bacterium

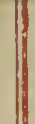

(1) 


\section{source Water}

\section{DETAILED FEATURES,}

NOTE-Underscore requlred terms. Ohserve notes nd glossary of terms on opposite slde of card.

1. MORPHOLOGY (2)

Form, round, short rods, long rods. short chains, long chains, filament, commas, short spirals,
long spirals, clostridium, cuneate, elavate, curved.
Lmits of size.../. $/$. .

Size of Majority..............

Orientation (groupi

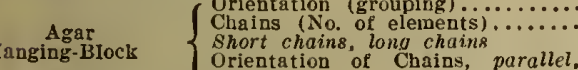

2. Sporangia, medium used..........temp..........

Form, eliipicalays short rods, spindled, clavate, drumsticks.
Linits of Size........ Size of Majority.........

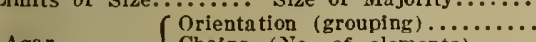
Agar
Chains (No. of elements)........
Oricutation of Chains, parallel.
irregular. Location of Endospores, eentral, polar.

Eordospores.
Form, round, clliptical, elongated.

Form, round, clliptical, elongated

Slze of Majority..........

Sporanglum wall, adherent, not adherent.
Germination, equatorial, oblique, polar, bipolar.

by stretching.
Flagella No......Attachment polar, bipolar, per itrichiate. How Stained...........

5. Capsules, present on.......

7. Involution Forms, on ........ ln...days at... ${ }^{\circ} \mathrm{C}$ Stalning Reactions.
$1: 10$ watery fuchsin, gentlan violet, carhol fuchsin, $1: 10$ watery fuchsin, gentlan viole
coeffer's alkaline methylene hlue.

Special Stalns

Fat................ Acid fast ............ Neisser.

11. CULTURAL FEATURES (3)

1. Agar Stroke, form of glowth, fliform, echinulate, beaded. spreading, plumose, arborescent, rhizoid.
glevation of growth, flat, elluse, taised. convex Lustre, glistening, dull, cretaceous. Topography, smooth contoured, rugose, verrucose.
Optical Characters.
opaque, translucent, opal. cscent, iridcscent.
cbromogenesis ( 8 )

Odor absent, decided, resemblina. $\ldots \ldots \ldots \ldots \ldots$
Consistellcy, slimy, butyrous, viscid, membranous, Consistelly, slimiy, butyrous, viscid, membranous,
coriaceous britile.
Medium grayed, browned, reddened, blued, greened. Medium grayed, browned, reddened, blued, greened.
Potato. Growti. scanty moderate, abundant, transient. porm of grow th, filiform, echinulate, beaded. spreading, plumse, arboreseent, rhizoid.

I.tsitre, glistening, dull cretaceous.
Topography, smooth. contoured. rugose, verrucose, Cbromogenesis (8) $\dot{Y} \in$. 11 . P.W pigment in water insoluble, soluble; other solvents..............

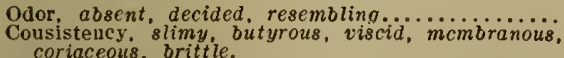
Cousiaceous, brittle.
Mediun, grayed, browned, reddencd, blucd, greened.

Stroke incisible, scanty. moderate, abundan roke incisible, scanty, moderate, abundant
Form of growth, filiform, echinulate, beaded spreading, plumose, arboresecnt, rhizoid.
Elevation of growtli. flat, effuse, raised, convex. Lustre, glistening, dull, cretaeous.
Topograllis, smooth, contoured, rugose, verrueose. Chromogenesis (8) ........ grayed, browned, redened, blued, greened. Liquefaction hegins $\ln \ldots . . . d$, complete in......d.

Agar Stab.
Growth uniform, best at top, best at bottom: sur.
face growth scanty, abundant; restricted, wide spread.
Line of puncture. filiform, baded, papillate, vil-

lous, plumose, arborceccint: liguefoction.

\section{Date of Isolation}

5. Gelatin Stab Growth uniform, best at top, best at bottom.
Line of puncture, fliform, beaded, papillate, viL lous, plumose, arborescent.
Liquefaction, crateriform, naporm, infundibuli form, saceate, stratiform; begins in.........d. complete in.........d.

6. Nutrient Broth.
Surface growth, ring, pellicle, flocculent, mem Surface growth, ring, pellicle, Rocculent, mem
branous, none. Clouding s.jaht, moderate, stron
persistent; none; fuid turbid. Odor, elsem, decided, resentbling................... Sedlment, compact, flocculent, granulä..... Maky,

7. Milk.

Clearing without coagulation.
Coagulation prompt, delayed, absent.

Extrusion of whey hegins in......... days.

Peptonization begins on.....d, complete on..... Reaction, 1d...2d...4 4d....10d.... 20d... Consistency, slimy, viscid, unchanyed.

Lah terment. present, absent. 8. Litmus Milk.
Aeid, alkaline, acid then alkaline, no change.
Prompt reduction, no reduction, partial slow re

Gelation. Colonies.
Gelat

Growth, slow rapid. l'orm, punetiform, round, irregular, ameboid.
mycclioid filanentous, hizod.
Elevation, fat, effuse, raised, convex, pulvinate, cratcriform (liquefying)
Edge, cutive, undulate. lobate, crose, lacerate Edge, futice, undulate, lobate, erore,
nimbriate, flamentous, flocose, curled
Liquefaction, cup, saucer, spreading.

10. Agar Colonies.

Glowth, slow, rapid, temperature.............. mycelioid. filamentous, rhizoid.
Surface smooth, rough, eoneentrically ringed, radi. ate striate.
Elevation, flat, effuse, raised, convex, pulvinate. umbonate.
Edge. entirc, undulate, lobate, erose, lacerate. fimbriate, floceose, curled.
Internal structure, amorphous, finely-, coarsely.

Starch Jelly.

Growth, scanty, copious.

Mfedium stalned....................

Silicate Jelly (Ferml's Solutiou
Growth copious, scanty, absent.

Medium stalned...

Growth, copious, scanty, absent.

Uschinsk"s Solution.

Growth copious, scunty. absen.

Sodium Chloride in Boullon.

15. Por cent inlibiting growth................ unre-

strained, feeble, absent.
17. Nltrogen.
Obtained from peptone, asparagin,

8. Best media for long-continued growth..

19. Quick tests for differential purposes....

\section{PHYSICAL AND BIOCHFMICAL FEATURES}

Fermentation-Tubes con-

taining peptone-water or

Gas production, in per cent

$\left(\frac{\mathrm{H}}{\mathrm{CO}_{2}^{-}}\right)$

No Gas

Growth in closed arm

Amourt of acid produced $\mathrm{d}$

Name Micrococcus Candicamiomp No. (1).

2. Ammonia production, feeble, moderate, strong, absent, masked by acids.

3. Nitrate in nitrate hroth,

Reduced, not reduced.

Presence of nitrites.

nltrates........ free nitrogen.

Toleration of Acids:

Acids tcsted...

G. Toleration of NaOH: Great, medium, slight.

7. Optimum reactlon for growth in boullion, stated in terms of Fuller's seale.

8. Vltality on culture media : brief, moderate, long.

9. Temperature relations:

Thermal death-point (10 minutes exposure in nutrient hroth when this is adapted to growth of Tranism: ..........

Optimum temperature for growth......... : or best growth at $15^{\circ} \mathrm{C}, 20^{\circ} \mathrm{C}, 25^{\circ} \mathrm{C}, 30^{\circ} \mathrm{C}$, 70 C, 400 C, 500 C, $600 \mathrm{C}$

Maximum temperature for growtb.........

10. Killed readily by drying: resistant to drying.
11. Pcr cent kllled by freezing (salt and crushed ice

12. Sunlight: Exposure on ice in thlnly sown agar plates: one-half plate covered (time $15 \mathrm{~min}$ plates: one-half plate covere

Per cent villed.

13. Acids produced

14. Alkalles produced

15. Alcohols

Ferments: pepsin, trypsin, diastase, invertase, pectase cytase, tyrosingse, aridase, peroxidase, lipaze, catalase, olucase, galactase. lab, etc....

17. Crystals formed:

18. Effect of germlcides:

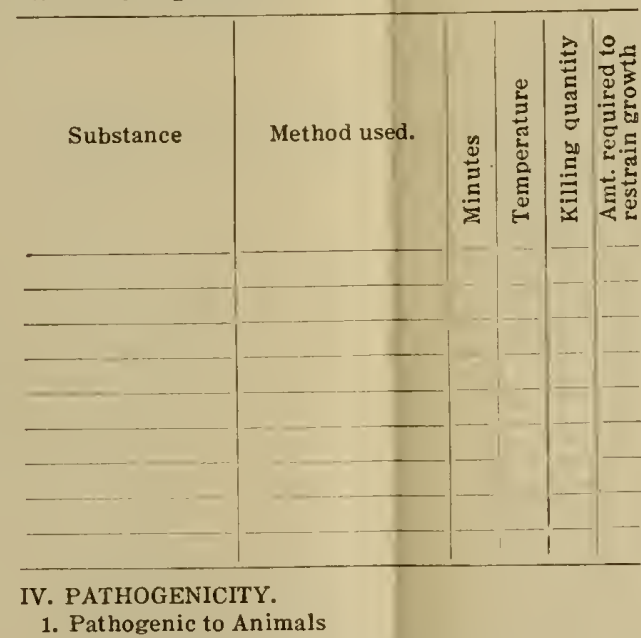

Pathogenic to Animals guinea pigs, rabbits, dogs, cats, sheep, goats, cattle, horses, monkeys, man..

2. Pathogenic to Plants

....................

3. Toxins, soluble, cndotoxins,

4. Non-toxin forming.

5. Immunity bactericidal

6. Immunity non-bactericidal.

6. Immunity non-bactericidal.
7. Loss of virulence on culture media: prompt, gradual, not observed in................months.
BRIEF CHARACTERIZATION Mark + or O, and when two terms occur on a line erase the one which

Diameter over $1 \mu$

Chains, filaments

Endospores

Capsules

Zoogloea, Pseudozoogloe

Motile

(C) Involution forms

Gram's Stain

Lloudy, turpid

Ring

Pellicle

Sediment

Shining

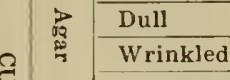

Roun

Proteus-like

$\checkmark$ Rhizoid

Filamentous

Curled

Qf Surface-growt

N Needle-growth

Moderate, absent

Abundant

Discolore

Starch destroyed

Grows at $37^{\circ} \mathrm{C}$.

Grows, in Cohn's Sol.

Grows in Uschinsky's Sol

ㄷ. Gelatin (4)

류 Blood-serum

i Agar, mannan

Acid curd

Rennet curd

Casein peptozized

Indol (5)

Hydrogen sulphide

Ammonia (5)

Nitrates reduced (5)

Fluorescent

Luminous

Animal pathogen, epizoon

Plant pathogen, epiphyte

Soil

Milk

Fresh water

Salt water

Sewage

Iron bacterium

Sulphur bacterium 


\title{
DESCIRIPTIVE CHART-SOCIETY OF AMERICAN BACTERIOLOGISTS
}

\author{
Prepared by F. D. CHESTER
}

$\left.\begin{array}{l}\text { F P. GORHAM } \\ \text { ERWIN F SMITH }\end{array}\right\}$ Committee on Methods of Identification of Bacterial Species.

ENDORSEd By the SOCIETy For General uSE at the ANNUAl MeEting, DeC. 31, 1907.

\section{GLOSSARY OF TERNS.}

AGAR HANGING BLOCK, a small block of autrient agar cut frum a poured plate, and placed on a cover-glass, the surface next the glass baving been first touched witb a loop from a soung fluid culture or with a dilution from the same.
lt is examined upside down, the same as a hanging drop. AMEBOID, assumiug various shapes like an ameba. A.IORPHOCS. Without visible differeatiation in structure Al:BORESCENT, a brauched, tree-like growtb.

BLADED. in stab or stroke, disjolated or semi-confuent colonles along the line of inoculation.

BRIEF, a few dass. a week.

BRITTLE arowth dry, erlahle under tbe platinum needlè.

BL'LLATE, growth rising in convex prominencea, like a hllstered surface.

BCTYROLS, growtb of a hutter-like consistency.

HANS.

Short chains, comnosed of 2 to 8 elements.

Long chains. composed of more than 8 elements.

CILIATE, having fine, hair-like extensious like cllia.

CLOLDY. said of fuid cuitures which do not contain pseudozoogloere.

COAGLLATION, the separation of casela from whey in milk. Thls may take place quickiy or siowly. and as the result either of the fornation of an acld or of a lab ferment.

CONTOLRED, an irregular. smoothly undulating surface. like that of a relief man.

CONVEX. surface the segment of a circle. but flattened.

COPROPHYL, dung hacteria.

CORIACEOLS, growth tough, leathery. not sielding to the piatinum needle.

CRATERIFORy. round. depressed, due to the liquefaction of the medium.

CRFTACEOCS. growth opaque and white, cbalks.

('TRLED. composed of parallel chains in wavs sirauls. as in

anthrax colonles.
DIASTASIC ACTION, Same as DIASTATIC, conversion of starch into water-suluble substances by diastise.

ECiINLLATE, in agar stroke a growth alcng line of fumculation. With toothed or nointed margins; in stub cuitures growth heset with pointed outurowths.

EFFT'SE. gTowth thin. velis. uuusually spreading.

ENTIRE. smooth. having a margin destitute of teeth or notrbes. EROSE. border irregularly toothed.

FILAJlEXTOCS, growth composed of long. irregularly placed or interworea flaments.

FIlAFORM. in stroke or stab cultures a uniform arowtb along line of inoculation.

FlMBRIATE, border fringed with alender processes. larger than

filaments.
FiOCCOSE, growtb composed of sbort curved chalas, variously oriented.

FloCCLLEIT, sald of buids whicb contain pseudozcogloeae. 1. e.. small adberent masses of hacteria of various shapea and floating in the culture flusd.

FI.:ORESCEST, having oae color is transmitted light and another b. retected light.

AII S STAL. a method of diferential bleaching after geatian violet. metbyl violet. etc. The + mark is to be given only
when the bacteria are deep hive or remain blue after when the bacteria are deep hive
coanterstalning with BIsmark brown.

Giri lusk clotted.

IXFUNDIBCLIFOR. form of a funnel or Inverted cone.

IIIDESCENT. like mother-of-pearl. The effect of very thiu blms. LACERATE. having the margin cut into irregular segments as If torn.

LOBATE. border deepls unduiate, prodaciag lobes (see undulate.) ioNG, maar weeks, or months.
MAXINUM TEMPERATLRE, temperature ahove whicb growth dies not take place.

MEDICM. several weeks.

MEMBRANOUS. growth thin. coherent. like a memhrane

MiNimum TEMPERATURE. temperature below which growth does not take piace.

MYCELIOID. colonies having the radiately fiamentoua appearance of mold colonies.

NAPIFORM, liquefaction with the form of a turaip.

NITROGEN REQUIRENENTS, the necessary aitrcgenous ford. This is determined by adding to nitrogen-free medis the nitrogen compound to be tested.

OPALESCENT, resembling the color of an opal.

OPTINUM TEMPERATURE, temperature at which growtb ia most rapid.

PELLICI.E, in fufd hacterial growth either forming a contlnuous or an interrupted sheet over the lluid.

PEPTONIZED, said of curds dissolved by trypsin.

PERSISTENT, many weeks, or months.

PLCMIOSE. a fleecy or feathery growth

PSELDOZOOGLOEAE, clumps of bacteria, not dissolving readily in water, arising from imperfect separation, or nore or
less fusion of the components, hut not having the degree of compactness and gelatinization seen in zoogloeae.

PLLViNATE, in the form of a custiou, decidediy convex.

PlNCTIFond. very minute colonies, at the linil of natural vision.

R.AISED, growth thick. With abrupt or terraced edges.

RHIZOID, growth of an irregular hranched or root-fike character as in $B$, mycoides.

RING. Same as RIM, growth at the upper margin of a liquid culture. adhering more or less closely to the glasa.

REPAND, wriukled.

PAPID Developing in 24 to 48 bours.

SACCATE, liquefaction the shape of an elongated aack tuhular. cylindrical.

loatiag islands of bacteria, an Interrupted pellicie or bacteriai membrane.

Therelopment.

SHORT, applicd to time, a few days, a week.

SPORANGIA. cells coutaining endospores,

PREADING, growth extending much beyond the liae of inoculation, $i$. e.. several millimeters or more.

tuhe at the tup and theu proceeding downwards liurizontalls.

THERMAL DEATH-POINT, the degree of heat required to vili young buid cultures of an organism exposed for 10 minutes (in tbin-walled test tuhes of a diameter not exceeding 20 $\mathrm{mm}$.) in the thermal water-bath. The water must he kept mm.l in the thermal water-bath. The water must he kept the exposure.

TRANSIENT, a few dass. focculent particles: clouls plus RiB. clou
flocculence.

UMBONATE. having a button-like, raised center.

WDULATE, border WaTs, TIth shallow sinuses.

VERRUCOSE. growth wart-like. with wart-1ike prominences.

VERMIFORM-CONTOURED, growth IIke a mass of worms, or intestinai coils.

VILLOUS. growth beset witb bair-dlke extenalons.

VISCID, growth follows the needle when touched and withdrawa, sediment on slaking rises as a coherent swirl.

ZOOGLOE.1E, firm gelatinous masses of hacterla, one of the most typical examples of which is the Streptococcus meenterioidcs of sugar rats (Leuconostoc mesenterioides) the bacterial chains belng surrouuded by an enormously thickenel firm covering. luside of which there may be one or many groups of the bacteria.
NOTES

(1) For decimal system of group numbers see Table 1. This Will he foud useful as a quick method of ahowing close rela-
tionslips inside the geuua, but ls aut a sufficient characterization (2) The morphological charactera shall he determined and
described from growtis ohtained upon at least one solid medium

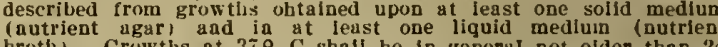
broth). Growth at 37 \% C shall be in general not oider than 24 to 48 bours, and growt ths at $20^{\circ} \mathrm{C}$ aot older than 48 to 72 hours. To secure uniformity in cultures. In all cases preliminary cultiva-
tiun shall he practiced as described in the revised Report of the tiun shall he practiced as descrihed in the

(3) The observation of cultural and blo-chemicel reatures shall cover a period of at least 15 days and frequeatly longer. and shall be made according to the revised standard Metind above referred to. All media shall be made according to the samo

(4) Gelatin stab cultures sball he beld for 6 weeks to deterine liquefaction.

(5) Ammonia a ad indol tests sball be made at end of 10 th day, nitrite tests at end of 5 th das.

(6) Titrate with N NaOH, usiag phenolphtbalein as an Indicator: inake titrationa at same times from hlank. The difference gives the amount of acid produced.
The titration should be done after bolling to drive of any The titration should Co2 present in the culture.
(7) Generlc nomenclature shall begin with the jear 1872

(Cola's Grst limportaut paper). (Koch' discovery of the poured piate method for the year 1880 Koch's discovery

(8) Chromogensis shall be recorded in atandard color terms. TABLE I.

NUMERICAL SYSTEM OF RECORDING THE SALIENT CHARACTERS OF AN ORGANISM. (GROUP NUMBER.)

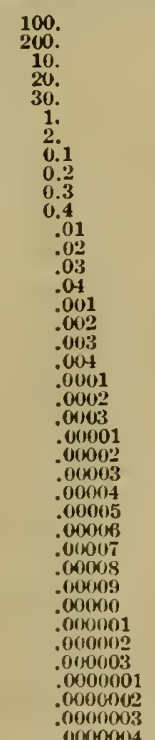
Endospores produced
Endospores not produce Facultative anaerohle Anaerohic (Strict) Acid aad gas trom dextrose
without gas from dextrose Acid without gas from No acid from dextrose Actd aud gas from luctuse Acid without gas frum No acid rom lactose
No growth witl lactuse Acid and gas from saceharose
Acid withuut gas from saccharose No acid frum sacchurnse Frowth with saccharose
iitrates reduced witb evoiution of gas Nitrutes not reducedl
Nitrates reduced witbout gas formation Nuorescent violet chromogeo

Biue
Gireen
Yellow
Orauge

Orange

Brow

Non-chromogenlc

Diastasic actiou on potato starch. atrong Diastasic action on potato starchion on potatehle Acid and gas from giycerine
Acid wittinut gas from glycerine No acid from glycerlue
No growth witli glycerine

The genus according to the system of Migula is The genus according to the system of Migula is
given its proper symbol wbicil precedes the number tbus: (?) BaCILLUS COLI (Esch.) Mlig. becomes B. 222.111102 BaCILLUS AlCALIGENES Petr. "“ B. 212.333102 PSEUDOMONas CaMPESTRIS (Pam.) Sm. “ “Ps. 211.33315 BACTERIUM SUICIDA NIIg. “ Bact, 222.232203

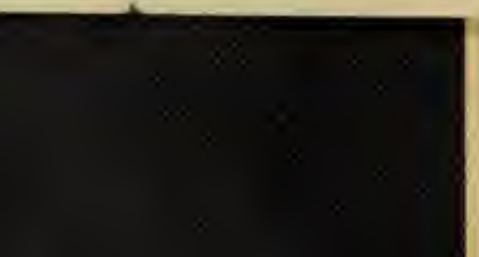




\section{DETAILED FEATURES.}

NOTE-Underscore requlred terms. Observe notes and glossary of terms on opposite side of card.

1. Morphorogx ${ }^{(2)}$ Cetative Cells, Medium used.. A.g.a ....

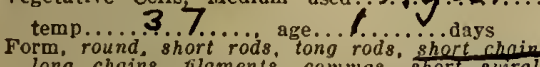
Form, round, short rods, tong rods, short chains,
long chains, filaments, commas, short sprats:
long spirals, clostridium, cuneate. clavate. curved.

Slze of Majorlty ..........

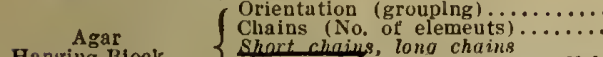
Agar
Hanging-Block $\left\{\begin{array}{l}\text { Ohhort chajins, long chains } \\ \text { Orientation of Chains, parallel. }\end{array}\right.$ 2. Sporangia, medium used..........temp.......... age..... elliptical, short rods, spindled, clavate, drumsticks.
Llmlts of Size......... Slze of Majority.........

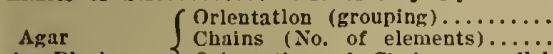
Agar
Hanglug-Bleck $\quad\left\{\begin{array}{l}\text { Chains (No. of elements)...... } \\ \text { Orientation of Chains, parallel. } \\ \text { irregular. }\end{array}\right.$ Location of Endospores, central, polar.

Fudospores,
Form, round, elliptical, clongated, Limits of Size.

Limits of Size.

Wall, thick, thin, adherent, not adherent. Germinatiou, equatorial, obliquc, polar, bipolar. Fiagella No....... Attachnent polar, bipolar, per itrichiate. How Stajncd....

5. Capsules, present on......

7. Involution Forms, on........n. . days at... ${ }^{\circ}$ Staing Reactions.
$1: 10$ watery fuchsin, gentlan violet, carhol fuchsin,
lieefler's alkaline methylene blue.

Sivecial Stalns $\ldots \ldots \ldots$ Glycogen

Fat............... Acld fast ...........

Neisscr

II. CulturaL Features (3

Agar Stroke.
Growth, invisible, scanty, inoderate, abundant
Form of growth, fitiform, echinulate, beaded, sprcading, plumiose, urturescent, rhizoid.
Elevatiou of growth, fiut, effuse, raised, convex Elevatiou of growth, git, efluse, raised, conves. Topograply, smooth contourcd, rugose, verrucose
Optlcul Characters, opaque, translucent, opas Chromogenesis (8) Green ish.

Odor abscnt, decided, resembling............. cariaecous britlie.
Mcdium grayed, browned, reddened, blued, grcened. 2. I'otnto. scanty. moderate, abundant, transient. persistent.
Form of growth. flliform. echinulate, beaded. Flevation of prowth, nat, effuse, raised, convex. custre, olistening, dult, cretaccous. Topograply, smooth, contoured, rugose, verrucose,
Chromogenesis (8) B.r.Q.W.ク Pigment in water insolublc, soluble; other solvents............. Odor, absent, decided, resembling . .............. coriaccous, brittle,
Mediuun, grayed, browncd, reddencd, blued, grcened. Mediuun, grayed, browncd, reddencd, blued, grcened, troke invisibte, scanty, moderate, abundant.
form of growth, fitiform. echinutate, beaded. spreading, plumose, arborescent, rhizoid.
Elevation of growth. flat, effuse, raised, convex. Lustre, glistening, dull, cret accous.
Topography, snlooth, contoured, rugose, verrucose.

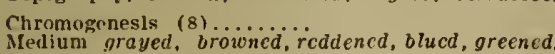
Melium grayed, browned, rcddencd, blucd, greened. Growth uniform, best at ton, best at bottom; sur-
face growth scanty, abundant; restrictcd. widcspread. Line of puncture, filiform, beaded. papitlate, vil
lous, plumose, arborfscent: tiquefuction.
5. Gelatin Stah.
Growth uniform, best at top, best at bottom.
Line of puncture, fitiform, beaded, papillate, vil lous, ptumose, arborescent.
Liquefaction, crateriform, naporm, infundibuliform, saccate stratiform; begins in........d.

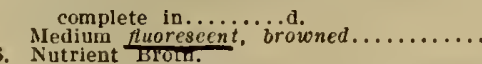

6. Nutrient Broth. ring, pellicle, flocculent, mem. Cloudling slight, moderate, strong; transient, persistent $;$ none; fluid turbid.
Odor, absent, dccided, resembling.

Sediment. compact. floceulent. granular. 'faky.

Milscid on agitation, abundant, scant.

Milk. Cling without coagulation.

d, absent.

Extrusion of whey begins in..........days.
Coagulum slowly pcptonized, rapidiy peptonizcd.

Peptonlzation bcgins on....d, complete on.....d

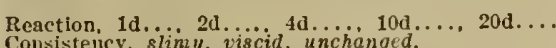
Mediun browned, reddcned, blued, greened.

Lab ferment. present, absent. 8. Litmus Milk. acid then alkaline, no change.
Acid, alkaline action the
Prompt reduction, no reduction. partial slow re$d u c t i o n$.
Gelatlu Colonics.

Growth, slow, rapid. myeclioid. filamentous, rhizoid.

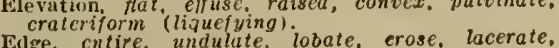
Edre. chtire, undulate, lobate, erose.
fimbriate. filamentous, foccose, curted.

10. factlon, cup, saucer.

Growth, stow, rapid, temperature.............

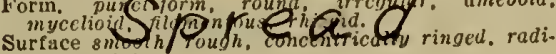
Elevation. Rat, ellusc, raiscd, convex, pulvinate, umbonate. finibriate, foocose, curled.
Internal structure, arnorphous, finely. coarsely-
aromular grumosc, filamentous, floccose, curled.

11. Starch Jelly

Girow th, scanty. copious.
Diastasic action, absent, feeble, profound.

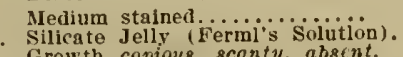

Growth copious, scanty, absin.

MIcdinm stained.

3. Cohn's Solution.

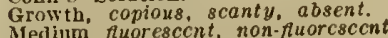

14. Uschinsky's Solution.
Growtly copious, scanty, absent.

Growt viscill. not viscid.

15. Per cent inhibiting growth................ unre-

16. Growth in Boullon over Chlorolort, unre-
strained, fceble, abscnt.

strained, fceble. abscnt.
17. Nitrogen.
Obtained from peptone, asparagin,
olycocoll urea, ammonia salts, nitrogen.

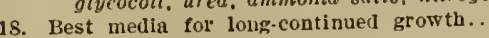

19. Quick tests for differential purposes....

III. PHYSICAL AND BIOCHEMICAL FEATURES

Fermentation-Tubes conSugar-free bouillon and

Gas production, in per cent

$$
\left(\frac{\overrightarrow{\mathrm{H}}}{\mathrm{CO}_{2}}\right)
$$

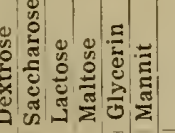

Growth in closed arm

$$
\text { NoGas }
$$

Amount of acid produced 1

absent, masked by acid
Nitrate in nitrate broth,
Reduced, not reduced.
Presence of nitrites.....

ammonla.

..... free nltrogen.

5. Indol production, feeble, moderate, strong. Acids tested.

6. Toleration of NaOH: Great, medium, slight.

7. Optimum reaction for growth in boullon, stated in terms of Fuller's scale...

8. Vitallty on culture media: brief, moderate, long.

9. Temperature relations:

Thermal death-point (10 minutes exposure in nutrient broth when this is adapted to growth of organism)......

Optimum temperature for growth.......... : or

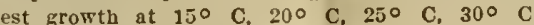
$37^{\circ} \mathrm{C}, 40^{\circ} \mathrm{C}, 50 \circ \mathrm{C}, 60^{\circ} \mathrm{C}$

Maximum temperature for growth.......... ilied readily by drylng. resistant to i.....

11. Per cent billed by freezing (salt and crushed lce or liquid air)...

12. Sunllght: Exposure on ice in thlnly sown agar plates: one-half plate covered (time $15 \mathrm{~min}$ utes), sensitive, not sensitive.

Per cent killed.

13. Acids produced

14. Alkalies produced

15. Alcohols

16. Ferments: pepsin. trypsin, diastase, invertase, pectase, cytase, tyrosinase oxidase, peroxidase. lipase, catalase, glucase, galactose, tab, etc....

17. Crystals formed:

18. Erfect of gernulcides:

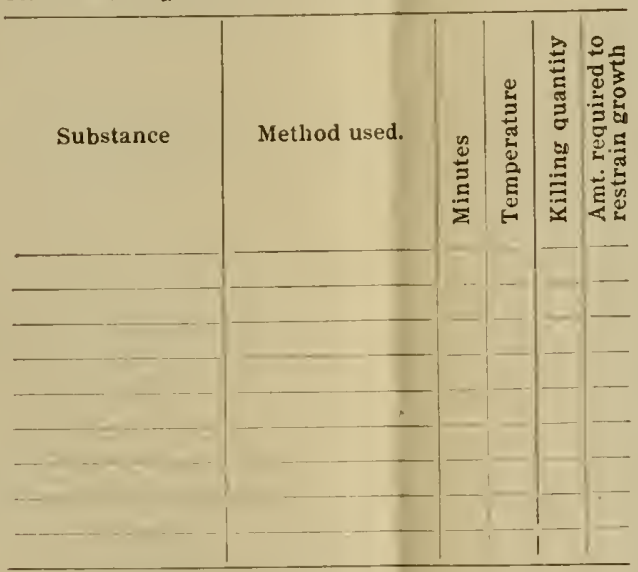

IV. PATHOGENICITY

Pathogenic to Animals guinea pigs, rabbits, dogs, cats, sheep, goats, cattle, horses, monkeys, man....

2. Pathogenic to Plants :

......................

3. Toxins, soluble, endotoxins,

4. Non-toxin forming.

5. Inmunity bactericidal.

6. Inmunity non-bactericida

7. Loss of virulence on culture media : prompt, gradual, not observed in ............... niontlis.
BRIEF CHARACTERIZATION Mark + or $O$, and when two terms does not apply unless both apply.

Diameter over $1 \mu$

Chains, filaments

Endospore

Capsules

Zoogloea, Pseudozoogloea

Motile

(C) Involution forms

Gram's Stain

turpid

Ring

Pellicle

Sediment

Shining

Dull

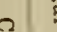

Wrinkled

Chromogenic

Round

(2) Proteus-like

$\rightarrow$ Rhizoid

Filamentou

दु Curled

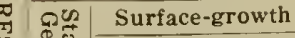

Needle-growth

- Abundant

$\frac{7}{6}$ Discolored

Starch destroyed

Grows at $37^{\circ} \mathrm{C}$

Grows, in Cohn's Sol.

Grows in Uschinsky's Sol.

Felatin (4)

苛. $\frac{0}{0}$

Agar, mannan

- Acid curd

Rennet curd

Casein peptozized

Indol (5)

Hydrogen suip hide

Ammonia (5)

Nitrates reduced (5)

Fluorescent

Luminous

Animal pathogen, epizuon

Plant pathogen, epiphyte

$\Xi$ Milk

Fresh water

Salt water

Sewage

Iron bacterium

Sulphur bacterium 


\section{DESCRIPTIVE CHART-SOCIETY OF AMERICAN BACTERIOLOGISTS}

Prepared by F. D. CHESTER

$\left.\begin{array}{l}\text { F P. GORIIAM } \\ \text { ERWIN F SMITH }\end{array}\right\}$ Committee on Methods of Identification of Bacterial Species.

ENDORSED BY THe SOCIETY FOR GENERAL USE AT THE ANNUAl, MEETiNG. DEC. 3I, 1907

GLOSSARY OF TERMS.

AGAR IIAXGGING BLOCK, a small block of uutrlent agar cut rroin a poured plate, and placed ou a cover-glnss, the surface next the glass having been first touched with a loop from a soung fuld culture or with a dilution from the same. AIEBOID, assuming varlous shapes like an amcba.

AlORPHOCS, without visinle differentiation in structure.

Al:BORESCENT. a branched, tree-like growtl.

BI:ADED, In stab or strokc, disjointed or semi-confuent colonies along the line of inoculation.

BRIEE; a few dass, a week.

BRITTLE, growth dry. friable under tbe plntinum needie.

BLLLATE. growth rising in convex prominences, like a bIstered surface.

BL'TYRO

Short chalns. composed of 2 to 8 elements.

Long cbalns. composed of more tban 8 elements.

CILIATE. baving fine, hnir-like extensions like cllia.

CLOCDY, sald of fluld cultures which do not contaln pseudozougloere.

COAGULATIOx. the separation of casein from whey in milk. This mas take place quickly or slowly. nnd as the result cither os the formation of an acia or or a lab ferment. that of a rellef map.

CONVE, sureace the serment of a circle, but flattened.

COPROPHYL dung bacteria.

CORIACEOrs, growth tough. leathery, not yielding to the plntinum needle.

CRATERIFORy, round, depressed, due to the liquefartion of the medium.

CRETACFOr'S, growth opaque nnd whlte, chalks.

CI'RLED. composed of parallel chains in wavy strands. ns in

DIASTASIC ACTION, Same as DIASTATIC. conversion of starch into water-soluble sulstances by diastase.

ECIIINLATTE, in agar stroke $\mathrm{n}$ growth alcng line of Inoculation. with toothed or pointed marglns: in stah cultures growth heset with pointed outarowths.

EFFI'SE, growth thiu, veily. unusualis spreeding.

EXTIRE. smoutl. haring a margin destltute of teeth or notcbes. EROSE, borlder irregularly toothed.

FILAJENTOCS. growth composed of long. Irregularly placed or interworen filaments.

FILIFORN. in stroke or stab cultures a uniform growtl along line of Inoculation.

FIMBRIATE, border fringed with slender proceses, larger than

Alaments.
CCOSE, growth composed of short curved cbalns, variously

oriented.
Floccilest, sald of fulds which contaln pseudozcogloeac, l. e.. smnll aulherent masses of bacteria of various shapes and floating in the culture fluid.

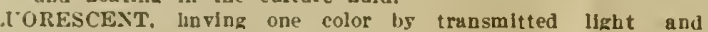
another by reflected light.

riflerentlal bleaching after gentlan whe + mark is to be given onls counterstaining with Bismnrk brown.

INFE.NDIBCLIFORM, form of a funnel or inverted cone. IRIDESCENT, like mother-of-pearl. The effect of rery thin films. LACERATE. having the margin cut into Irregulnr segments as is torn.

(see undulate. Loxf, many reeks, or months.
MAXIMUN TEMPERATURE. temperature above whlch growt does not take place.

NFUBRANOUS, arowth thIn coberent, IIte a membrane.

MINIMUN TEMPCRATURE, temperature below whicb growt does not take plnce.

MYCELIOID, colonies having the radiately flamentous appearnnce of mold colonies.

NAPIFORM. liquefaction with the form of a turnip.

NITROGEN REQCIRENENTS. the necessnry nitrcgenous focd. This is detcrmined by ndding to nitrogen-frec media the nitrogen compound to be tested.

OPALESCENT, resembling the color of an opal

OPTIMUM TEMPERATURE. temperature at which growth is most rapid.

PELLICLE, in fluld bacterial grorth eitber forming a continuous or au interrupted shect over the fuid.

PEITONIZED, said of curds dissolved by trypsin.

PERSISTEXT, mnny weeks. or munths.

PLCMIOSE, a fleecy or feathery growth.

PSECDOZOOGLOEAE, clumps of bacteria, not dissolving readily in water. arising from imperfect separation. or more or less fusion of the components, hut not haviug the

PULVINATE. in the form of a cuslion, decidediy conver.

P[XCTIFoRM, very minute colonies, at the Iinlt of natural vlsion.

RAISED. growth thick, with abrupt or terraced edges.

IHIZOID. growth of an irregulnr branched or root-like claracter. as in $B$. mycoides.

ING. Same as RIM. growth at the upper margln of a liquld culture, adbering more or less closely to the glass.

REPAND. wrinkled.

RAPID. Developing in 24 to 48 bours.

SACCATE liguefaction the shnpe of an elongated sack, tubula cyllndrical.

SCCM. floating Islands of bacterla, an Interrupted pellicle or bacterial membrane.

SLOW, requiring 5 or 6 days or more for development.

SIIORT. applicd to time, a few days. a week.

SPORANGIA, cells containing enduspores. inoculation, $i$. e.. several millimeters or more.

STRATIForM. liquefsing to the wnlls of the tube at the top and then proceeding downwnrds hurizontalls.

THERMAL DEATII-POINT. the degree of heat required to kII soung fuid cultures of an organism exposed for 10 minutes (in thin-walled test tubes of a diameter not exceeding 20 $\mathrm{mm}$.) In the thermal water-bath. The water must be kept agltated so that the temperature sball be uniform during the exposure.

TRAXSIEAT, a fetr days

TURBID. cloudy with focculent particles: cloudy plus flocculence.

UMBONATE. baving n button-like, raised center.

L'NDULATE, border wavy. With shallow sinuses.

VERIsc COSE. growth wart-like, with wart-like prominences.

VERMIFORNI-CONTOURED, growth like a mass of worms, or intestinal colls.

VILLOUS. growth bcset witb hair-like extensions.

VISCID. growth follow's the needle when touched and withdrawn, sediment on shaking rises as a coherent swirl.

ZOOGLOEAE. firm gelatinous masses of bacterla. one of the inost typical examples of which is the streptococcus mescnterioides of sugar vats (Leuconostoc mesenterioides). the bacterlal chalns belng surrounded by an enormously thickenet arm covering. inside of whlch there may be one or man groups of the bacteria.
NOTES.

(1) For decimal system of group numbers see Table 1. Thls will be found uspful as a quick metherd of showing close rela
tionships iuside the genus, but is not a sufficleut characterizatlon of uny orgauisn.

(2) The morpbological cbaracters shall be determined and (nutrient agar) and in at broth). Growths at 37 o C shall be ln general not older than 24 to 48 hours, and growths at $20^{\circ} \mathrm{C}$ not older than 48 to 72 hours. tion shall be practiced as described in the revised Report of the Commitee on Stanclarl Methofs of the Lah
Anerican Public Health Association, 1905 .

(3) The observation of culturnl and blo-cbemienl features shall cover a period of at least 15 dass and frequently longer. above referred to All media sball be made according to the same Standard IIethods.

(4) Gelatin stab cultures shnll be held for 6 weeks to determive liquefaction.

(5) Ammonia and indol tests sball be made at end of 10th day, nitrite tests at end of 5 th day.
(6) Titrate with $\mathrm{N}$ NaOH, using phenolphthaleln as an indicator: inake titrations at same times from blank. The differeuce gives the amount of acid produced.
The titrntion should be done after bolling to drive off ang Co2 prescnt in the culture.

(7) Generle (7) Generlc nomenclatare
(Colin's first importaut paper).

Species nomenclature shall begin with the ycar 1880 (Koch's discovers

(8) Chromogensis shall be recorded in standard color terms. TABLE. I.

A NUMERICAL SYSTEM OF RECORDING THE SALIENT CHARACTERS OF AN ORGANISM. (GROUP NUMBER.)

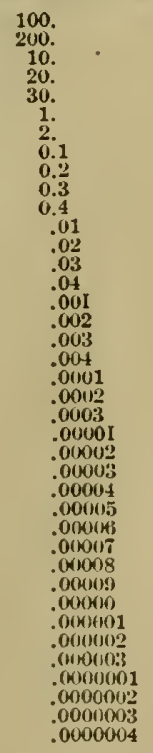

ndospores not produce

Aerohic (Strict)

Anaerobic (Strict)

elatin not liquefied

Acid and gas from dextrose

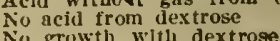

No growth with dextrose

Acld and gas from lactuse
Acid without gas trom lactose

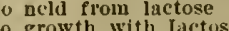

Acid and gas from saccharose

No acid from saccharose No growtb with saccharose
Nitrates reducel with evoiution of gas itrates not reduced Finorescent
Violet ciromogens

Green
Yrilinw
Orange
Red

Rrown

on-chromogenic

on potats starch, strong Nastaste action on potato starch, Peeble Acid and gas from plycerine No acld from glycerine
No growth with glycerine

The genus according to the s5stem of MIgula is glven its proper ssmbol which precedes the number thus: (7) becomes B. 292.11110 Baclllus coli (Esch.i Mig. BACILlUS ALCALIGENES Petr. $\begin{array}{llll}\text { PSEUDOMONAS CAMFESTRIS (Pam.) Sm. “ } & \text { I's. } & 211.333151 \\ \text { BACTERIUMI SUICIDA N1Ig. } & & & \end{array}$

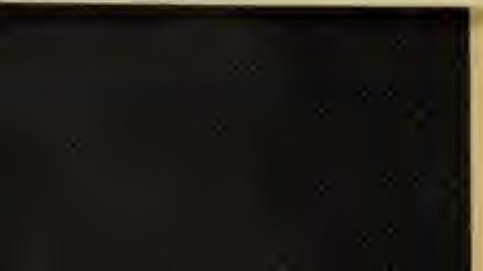




\section{BIBIIOGRAPHY}

1. Mioroorganisms in Water. Peroy and G. C. Frankland. 1894. p. 105.

2. Water Supplies. Savage. 1906. Chapter IX.

3. Elements of Water Bacteriology. Prescott and Finslow. 1913. p. 23.

4. Examination of Hater and Fater Supplies. 1912.

5. Notes on the Distribution of B. coli. Flint. Jour. Amer. lifod. Assn. 1896. Vol. 26. p. 410.

6. Zur Iohre über das Bacterium coli commune. Belitzeo. Rev. Jahresbericht uber die Fortschritte in der

Lehre den pathogenen Ilikroarganismen. Vol. 25. p.326.

7. a Notes on INormal Intestinal Baciliz of the Eorse and of Certain Other Domesticated mimals. Dyer and Kleth.

Teoh. Quarterly. VoI. 6. p. 256.

7.6 The 0courrence of Organisms of Sanitary Significance on Grains. Prescott.

B10l. Studies of Pupils of H. T. Sedgwiok. 1906.

8. Organisms on the Surface of Grains with Special Reference to B. coli. Netcalf.

oct. 6, 1905. Science. V01. 22.

9. Occurrence on Grain of Organisms Resembling the B. coli communis. E. G. Smith.

Sclence. Vol. 21. p. 710 . 

10. Iritische una experimentelle Beiträge zur hygienischen Beurteilung des Massers. Kruse.

Zeit. I. Hyg. Vol. 27. p. I.

11. Ueber die typhus "ahnlichen Bakterien des Strassburger Wasserleitungswasser. Beckmann.

Arch. f. Exp. path. und Pharm. Vol. 33. p. 466.

12. Bakterium coll commune. Maroni.

Arch. per le Scienoe medich. Vol. 22. p. 261.

13. Der Befund des Bakterium coli im Wasser und das Teirexperiment sind kelne brauchbare Hüfmittels fur die Fygienische Beurteilung des Wassers. Weissenfeld.

Zeit. 1. Hyg. Vol. $35 . \mathrm{p} .78$.

14. The Distribution of Bacterium col1 commune. Chiok.

The Thompson Yates Lab. Reports. Report 3. p. 1 .

15. The Colon Bacillus in Ground Waters. Horton.

Publ10 Health. VoI. 28. p. 419.

16. The Sand Filtration and Purification of Chalk Waters.

Nankivell. 1911. Jour. of Hyg. Vol. 11. $\mathrm{p} \cdot 235$.

17. Experiment Relating to WelI Contamination at Quitman, Ga.

Mac Callie. Water Supply Paper. No. 110. p. 145.

18. Use of Flourescein in Tracing Waters. R. B. Dole.

Water Supply Paper. No. 160. p. 73.

19. Sur I'emplo1 matieres coulerantes pour la recherche de I'origin des sources et des eaux d'infiltration. Trillat. Compt. Rend. 1899. Vol. 128. p. 698.

20. Contribution $I^{\prime}$ tude des ealus souterraine. liarboutin. Compt. Renā. 1901. Vol. 132. p. 365. 

21. Sur I'application de Ia flourescein a I'hydrologie souterraine. Iiartel.

Compt. Rend. 1903. Vol. 137. p. 225.

22. Bakteriologisohe Untersuchungen des Trinkwassers der Stadt Kiel im sugust und September 1887. Kiel 1888.

23. Is the Colon Bacilius a Normal Inhabitant of the Intestine of Fishes. imyot.

Publio Health. Vol. 27. p. 400 .

24. Isolation of $B$. coli from the elinentary tract of fish and the Significance thereof. Geo. L. Johnson. Jour. Inf. Dis. Vol. I. p. 348.

25. A Comparison of B. coll communis from Different species of inimals. Hoore and Wright.

Jour. Bost. Med. Soc. Vol. 4. R. 175.

26. Distribution of B. coll in Nature. Eyre, J. W. E. Lancet (1904). VoI. I. p. 648 . 
Eet?

Q

8. 10

4

3.

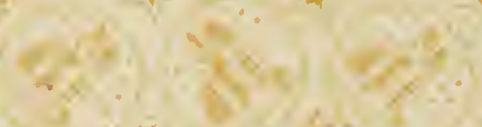

a) 160

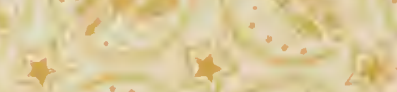

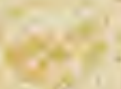

(5)

है

a

$\infty$

s

Y

18

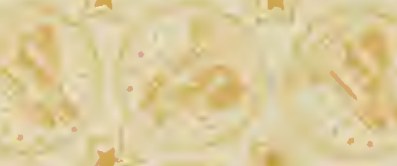
ix:

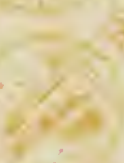
皮
es
38
48
$1+\frac{2}{2}+2$
8

$7 \times 19$

12

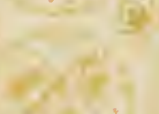

9

18

$\therefore-1,4$

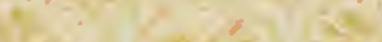

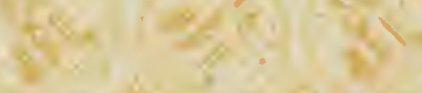

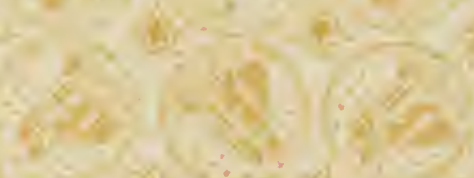

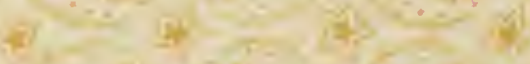

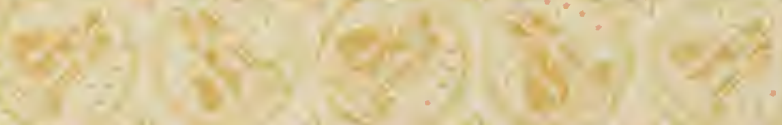

$\frac{1}{6}$

18

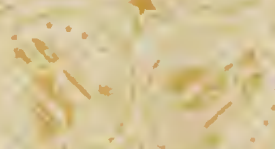

$x_{x}^{4} \frac{\pi}{1}$

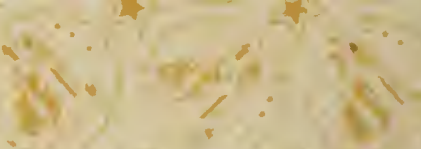

$81-1,2 \%$ 
